\title{
The Voice-Over of Administration: Reading Ottoman Archives at the Risk of Ill-literacy
}

Marc Aymes

\section{(2) OpenEdition \\ Journals}

\section{Electronic version}

URL: http://journals.openedition.org/ejts/1333

DOI: $10.4000 /$ ejts. 1333

ISSN: $1773-0546$

Publisher

EJTS

\section{Electronic reference}

Marc Aymes, «The Voice-Over of Administration: Reading Ottoman Archives at the Risk of II-literacy », European Journal of Turkish Studies [Online], 6 | 2007, Online since 27 December 2007, connection on 16 February 2020. URL : http://journals.openedition.org/ejts/1333; DOI : 10.4000/ejts.1333 


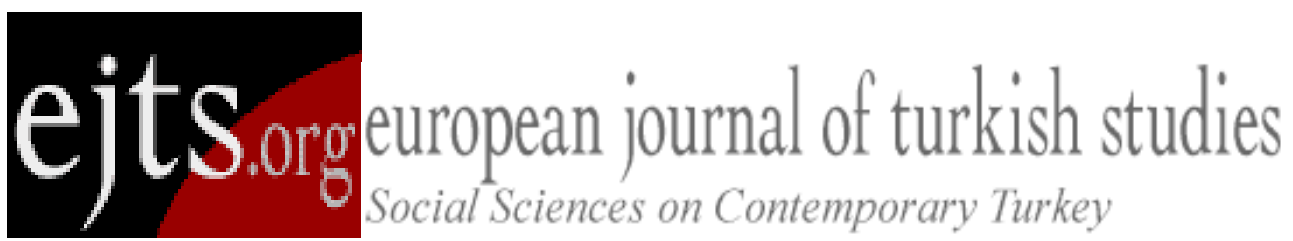

Citation : Aymes, Marc (2007) 'The Voice-Over of Administration: Reading Ottoman Archives at the Risk of III-literacy', European Journal of Turkish Studies, Thematic Issue $N^{\circ} 6$, III-literate Knowledge, URL: http://www.ejts.org/document1333.html

\title{
The Voice-Over of Administration: Reading Ottoman Archives at the Risk of III-literacy
}

Marc Aymes

\begin{abstract}
Although the Ottoman state has deservedly been considered a world of paper in itself, and an overflowing one at that, its protagonists also had reasons not to rely on written documents. Drawing on archives from the $19^{\text {th }}$-century Ottoman administration, and focusing on the province of Cyprus, the present article unearths the oral and aural authority on which imperial rule rested. It shows that this authority was embedded, thanks to a semantic interplay of cultural and religious references, in the language of administration. It proceeds through a semantic review of the various turns of phrase that Ottoman officials and provincial 'notables' employed in the business of provincial rule, arguing that their administrative taxonomies could be challenged, unraveled or stained by the rogue words of their 'common' interlocutors. Scholarly readings of the Ottoman archives hence need to acknowledge the oral character of these lettered pieces, and to account for the dissension of unpalatable utterances troubling their graphic order.
\end{abstract}


Citation : Aymes, Marc (2007) 'The Voice-Over of Administration: Reading Ottoman Archives at the Risk of III-literacy', European Journal of Turkish Studies, Thematic Issue $N^{\circ} 6$, III-literate Knowledge, URL: http://www.ejts.org/document1333.html

To quote a passage, use paragraph (§).

'Every place in this island is fertile and fruitful, to the extent that it is impossible to describe it with a pen.'

Welcome to a world of archives: the Ottoman administration in the mid-19th century ${ }^{1}$. Or, rather, what remains of it. An ever-mutating profusion of letters sedimented on paper. Pacing its files and folders requires determination and patience. Plunging into the task of reading supposes that we endorse a twofold, almost unconscious assumption: these writings were intended to be read; and they indeed could be.

[2] Such a hypothesis yet implies that we rule out the possibility of illiteracy (not to mention sheer analphabetism ${ }^{2}$ ), while much evidence points to the contrary. An Ottoman official sent to the province of Cyprus by the Istanbul government in the early 1850s, 'Alī Sırrı Efendi, thus points out that 'in some villages nobody can read or write'. . And a memorandum drafted at the Sublime Porte in 1847 clearly states that among the very members of the Empire's provincial officialdom, certain subaltern agents might be unable to sign their own name ${ }^{4}$.

${ }^{1}$ Many thanks to the EJTS editorial board members, and to the two anonymous referees, who read the drafts of this article, commented on it, and edited the final text for online publication.

${ }^{2}$ The distinction suggested here is that, while 'illiteracy' points to people who did acquire some reading and writing abilities, yet lost them later on, 'analphabetism' refers to people who never acquired such abilities (see Lahire 1999). It is worth keeping this nuance in mind, although the materials studied in what follows do not allow to fully elaborate on its implications.

${ }^{3}$ BOA, I.MVL 7270 (n.d. [ 1850-51]): 'ba'zı köylerde yazı bilür kimesne bulunmadıġı'. (All translations in this article are the author's, except otherwise stated.)

${ }^{4}$ BOA, A.MKT 107/33, draft of a memorandum sent to several provincial governors (n.d., two distinct dates overleaf: 17 Muharrem 1264 [25 December 1847] and 2 Safer 1264 [9 January 1848]): 'kendüsi yazı yazmak bildigi hālde kendü hattıyla [...] yazub yazı bilmedigi sūretde başka yazı ile yazdırılub'. Also see Bouquet 2007: 72 (concerning regulations issued by the Ottoman administration in 1879): 'Si l'administration préfère que le serviteur réponde lui-même aux questions posées, elle envisage qu'il ne puisse le faire: elle intègre sans doute la réalité du degré d'alphabétisation de l'époque, même dans le lieu privilégié de la pratique scribale qu'est l'administration civile.' 
Citation : Aymes, Marc (2007) 'The Voice-Over of Administration: Reading Ottoman Archives at the Risk of III-literacy',

European Journal of Turkish Studies, Thematic Issue $N^{\circ} 6$, III-literate Knowledge, URL: http://www.ejts.org/document1333.html

To quote a passage, use paragraph (§).

[3] These preliminary remarks point to the array of issues one has to confront when entering the Ottoman world of paper. To what extent did the 'users' of such documents, be they writers, readers, beholders or listeners, rely on these written pieces? By focusing on the case study of Cyprus, the following argues that Ottoman provincial administration was deeply dependent on the power of an oral authority that was embedded, thanks to a semantic interplay of political and religious traditions, in the language of administrators; hence, most of the latter's written correspondence, as it has been kept to date, ought to be read as oral archives. Simultaneously, one is also led to conclude that the enactment of such an oral authority within the administrators' written correspondence required them to enhance their aural perspicacity, underpinned by taxonomic overtones, so as to come to grips with the challenge of profuse rumours.

[4] Thus, in the documents that $19^{\text {th }}$-century Ottoman provincial administrators left behind, established literacy remains exposed to the risk of a twofold abolition: more often than not it needs the rarefied sponsorship of unwritten words; but sometimes, all of a sudden, it gets overwhelmed by the tumult of inconsistent multitudes.

\section{In Default of Letters: Oral Archives}

[5] During the nineteenth century, the idea of a profound transformation of state organisation and government procedures gained momentum among the rulers of the Ottoman Empire. While reframing the secular buttresses of the sultan's sovereignty, it aimed at overhauling the day-to-day management of Ottoman administration. These 'Tanzimat', as they came to be known for posterity', manifest themselves at first sight as a 'flood of statutes, regulations, laws and by-laws' (Mardin 1989: 114) engulfing Ottoman archives from that time. Yet, for all the 'paper-pushing routine' (Mardin 1962: 118) that such decisions unleashed, there might have been something about the Tanzimat that took place outside the world of paper. In other words, and contrasting with a commonplace saying that

${ }^{5}$ The word literally means 'reorganizations', though 'reforms' has been the prevalent translation in scholarly publications to date. 
Citation : Aymes, Marc (2007) 'The Voice-Over of Administration: Reading Ottoman Archives at the Risk of III-literacy',

European Journal of Turkish Studies, Thematic Issue $N^{\circ} 6$, III-literate Knowledge, URL: http://www.ejts.org/document1333.html

To quote a passage, use paragraph (§).

disparaging observers ${ }^{6}$ or dispirited historians ${ }^{7}$ have been fond of, the decisions taken did not remain only 'on paper': more often than not, they could be issued and enforced without leaving any written trace behind. The thing is, Ottoman administrators had reasons not to stick to writing.

\section{Sweet Talk: Coming to Terms with Local Circumstances}

[6] One soundbite permeates the archives of Ottoman administration in these years of 'reforms': any new regulation should be 'arranged so that it be understood by everybody' ${ }^{8}$. Now, due to the lack of literacy prevailing among the Empire's populations, such an endeavour implies that oral expression back up written prescriptions. A recurring phrase manifests this conjunction: orders sent from Istanbul to the province are usually, when the moment comes to inform the people about their content, 'unfolded and pronounced' (feth ü kırā'at) by local administrators ${ }^{9}$. Be it during a council meeting, in the provincial capital (Lefkoşa) ${ }^{10}$ or in a subdistrict seat ${ }^{11}$, or during a religious celebration, in a church or a mosque ${ }^{12}$, - each time the letter deposited on folded paper is made present by being read aloud ${ }^{13}$.

${ }^{6}$ E.g. Savile 1878: 136 (as quoted in Hill 1972: 25): 'It seems that in Cyprus it is not so much the laws themselves, but rather the administration of the laws which needs reform.'

${ }^{7}$ E.g. Ma'oz 1968.

${ }^{8}$ BOA, A.MKT 21/97, note (kāime) drafted at the Sublime Porte (n.d. [ 1844-45]): "herkesiñ añlayacaǵı sūretde bir kıt'a nizām-nāme tanzīm.' Concerning this question, and the tranformations that it brought about in the writing practices of $19^{\text {th }}$-century Ottoman administration, see Aymes (forthcoming).

${ }^{9}$ BnF, Suppl. turc 1042, instructions to Mehmed Es'ad Beg (n.d. [ autumn 1831]), f. 19: 'yedine dahī fermān-I 'ālī virilmiş olmag̉la muktezā-yı me'mūriyeti üzere bu tarafdan hareket ve serī'en ol-cānibe vārub emr-i 'ālīi mezkūrı 'alenen feth ü kırā'at itdirerek [...]'.

${ }^{10}$ BOA, A.MKT 19/7, report by the governor of Cyprus İbrāhīm Edhem Paşa (23 Zī'l-ka'de 1260 [4 December 1844]): 'nizām-nāme-i seniyye-i mezkūre Lefkoşa meclisinde feth ü kırā'at'.

${ }^{11}$ BOA, I.DH 17572, round robin (mahzar) from the authorities of the Mesārya district (Şevvāl 1269 [JulyAugust 1853]): 'sūret-i buyruldı 'alenen feth ü kırā'at'.

${ }^{12}$ Ibid., round robin (mazbata) signed by Mehmed Rā'if, defterdār and kā'im-makām of the White Sea Islands governor-general (vāli), and other local authorities (19 Şevvāl 1269 [26 July 1853]): 'iki kıt'a buyruldı-ı müşīrāneleri [...] kil̄̄sālara feth ü kırā'at.' See also BOA, A.MKT 198/76, mazbata from the Islands council (2 C 1265 [25 April 1849]): 'nizāmnāme-i mezkūruñ ahkāmı bi-I-cümle cevāmi' ve mesācid ile kinīsālarda kırā’at'.

${ }^{13}$ For similar examples of 'proclamations to be read aloud' in early modern England, see Thomas 1986: 106107. 
Citation : Aymes, Marc (2007) 'The Voice-Over of Administration: Reading Ottoman Archives at the Risk of III-literacy',

European Journal of Turkish Studies, Thematic Issue $N^{\circ} 6$, III-literate Knowledge, URL: http://www.ejts.org/document1333.html

To quote a passage, use paragraph (§).

[7] Oral utterance then seems to redouble the awaited effectiveness of any written order, by ensuring due repercussion to the rules laid down on paper. Yet there also exist orders whose promulgation needs no written inscription: these are essentially oral, and only subsequent reports allow us to catch their tenor. For instance 'Ömer Paşa, a military officer dispatched to Cyprus from Beyrouth lest some trouble could take place in the island in 1841, reports that the instructions he delivered to his troops were 'transmitted orally' ${ }^{14}$. When, in late 1844, the governor of the island İbrāhīm Edhem Paşa passes on to district council authorities a regulation concerning the necessary 'regularity' of their reports, he stresses that he 'expressed orally' to them their obligation to conform to this rule ${ }^{15}$. Again, when the high official (and former minister of Finance) Mūsa Safvetī Paşa comes to office as a governor-general of the White Sea Islands in spring 1849, not only does he send a series of written instructions to his 'substitutes' and other local administrators, but he also addresses to each island local council a set of grandiloquent 'oral orders' (vesāyā-yı şifāhiyye) ${ }^{16}$. Today one can only read the 'copy' (sūret) that Safvetī Paşa deemed useful to have written down: writing remains second to utterance.

[8] On these matters, the round robin that the main Cyprus authorities cosigned following Safvetī Paşa's visit to Lefkoşa in early June 1849, reveals a crucial detail:

[9] During the council meeting held in the fortune-lavishing presence of His Marshal Excellency [...] we humbly gained knowledge of the sultanic oral order concerning the indispensable tax increase by three hundred and fifty thousand piastres, along with the substance of the ever-generous vizirial decree that was subsequently addressed to the high person of His Excellency, praised for his qualities, by the sublime vizirate endowed with exalted feats ${ }^{17}$.

${ }^{14}$ BOA, I.MVL. 352, report by the commander (mīr-livā) 'Ömer Paşa (n.d. [ 1841-42]): 'tenbīhāt-ı lāzıme telkīn ü tefhīm'.

${ }^{15}$ BOA, A.MKT 19/7, report by İbrāhīm Edhem Paşa (23 Zỉ'l-ka'de 1260 [4 December 1844]): 'nizām-nāme-i seniyye-i mezkūreniñ birer 'aynısı dahī taşra kazālarda kā'in meclislere i'tā olunarak mantūk-ı münīfi üzere 'amel ü hareket eylemeleri husūsı ifāde ü telkīn olunmuş'.

${ }^{16} \mathrm{BOA}$, I.DH 11188, 'copy of oral orders proclaimed before the councils in meeting, copies of which in Turkish and Greek versions have been handed out to all' (mecālis-i mün'aqıdede ifāde ile Türkī ve Rūmī sūretleri cümleye virilen vesāyā-yı şifāhiyye sūreti) (n.d. [ B 1265/May-June 1849]).

${ }^{17} \mathrm{lbid}$., round robin signed by the main authorities of Cyprus (governor excepted) (15 Receb 1265 [6 June 1849]) (stress added): 'huzūr-ı meyāmin-mevfūr-ı müşīrānelerinde ma'kūd meclisde [...] üc-yük elli biñ guurūşuñ be-heme-hāl tevzīe idhāliyle tahsīli hakkında vāki' olan irāde-i şifāhī ve ol-bābda iktizāsınca zāt-ı sütūde- 
Citation : Aymes, Marc (2007) 'The Voice-Over of Administration: Reading Ottoman Archives at the Risk of III-literacy',

European Journal of Turkish Studies, Thematic Issue $N^{\circ} 6$, III-literate Knowledge, URL: http://www.ejts.org/document1333.html

To quote a passage, use paragraph (§).

[10] The sultanic order (irāde) then can remain oral; and only when it enters the offices of the Grand Vizier does it turn into the written form of a 'letter of order' (emir-nāme). Moreover, far from being a marginal expedient, a condescending recourse that Ottoman officials would use only while addressing their presumably illiterate provincial subordinates, this practice of orality stands at the highest of imperial administration, involving the core of decision-making within the Sublime Porte. Quite frequent indeed are 'the orders given orally by the sultans, on all sorts of topics' ${ }^{18}$. More often than not, there is a chance that their gist might have been laid down by some palatial secretary, and scholars familiar with Ottoman diplomatics know where to find them: they would be written diagonally as annotations to the 'memos' ('arż tezkiresi) submitted to the Palace by the Grand Vizier offices. And yet,

[11] it is difficult to assert that memos from the Grand Vizirate that bear no irāde, examples of which one often comes across in the archives, have not resulted in any sultanic order. For, decision about them might have been taken orally as well ${ }^{19}$.

[12] Blank as its archives may remain, the sovereign's authority has its many ways to express and convey its wills in due form. Transmission by word of mouth is not the least.

[13] Orality thus appears to be a paramount mode of command in the Ottoman administration. Does it imply, yet, that its stakes and ends are the same in Cyprus and in Istanbul? The hypothesis adopted here is that in provincial contexts the use of oral orders means something peculiar. Let us sift through the occurrences of such orders here and there in the achives of provincial administration, so as to determine the circumstances they are related to. And first, one may go back to Safvetī Paşa's orders to the Islands council members in 1849. For, another of his reports sent the same year sheds light on the reasons why he deems oral communication so important ${ }^{20}$. In this document, the governor-general echoes the complaint by the inhabitants of several islands that the

sıfātlarına hitāben cānib-i ma'ālī-menākıb-ı sadāret-'uzmādan şeref-vürū[d] olan emirnāme-i sāmiyye müfād-ı mekārim-'ādīsinden ma'lūm-ı çākerânemiz olmuş.'

${ }^{18}$ Akyıldız (1995: 224) duly stresses the importance of the 'şifahî irâdeler', these 'padişahların herhangi bir konuda sözlü olarak verdikleri emirler.'

${ }^{19} \mathrm{lbid}$ : 225 ('arşivde sık sık rastlanılan irâdesiz sadâret tezkirelerinin irâdelerinin çıkmadığını söylemek ve iddiâ etmek güçleşmektedir. Zirâ, bu tezkirelerin irâdeleri de şifahî olarak verilmiş olabilir.')

${ }^{20}$ BOA, A.MKT 211/63, report ('arīza) by Safvetī Paşa (7 Receb 1265 [29 May 1849]). 
Citation : Aymes, Marc (2007) 'The Voice-Over of Administration: Reading Ottoman Archives at the Risk of III-literacy',

European Journal of Turkish Studies, Thematic Issue $N^{\circ} 6$, III-literate Knowledge, URL: http://www.ejts.org/document1333.html

To quote a passage, use paragraph (§).

Archipelago teems with 'robbers' (hırsızlar) and 'privateers' (korsān). While soliciting the assistance of ships from the Ottoman Fleet in the near future, he carries on explaining that he already hardened the application of 'rules regarding permits [of passage] and quarantine.' Besides, he adds, 'the people of the islands have been coaxed through certain verbal orders [vesāyā-yı lisāniyye] ${ }^{21}$. Stress is to be laid here on the word 'lisān.' It literally means 'tongue', in both senses of the term - system of communication and organ of speech ${ }^{22}$. While it may be taken as referring to any language, idiom or dialect, here it clearly means a spoken, uttered language ${ }^{23}$. And significantly enough, this verbal orality here appears endowed with mysterious powers of 'conciliation' (istimālet). It is important to fathom how deeply rooted in the political idealism of sultanic classicism this latter notion is. As a matter of fact, in the centuries of Ottoman expansion, sultans used to secure the loyalty of newly conquered provinces by measures of this 'conciliatory' kind, namely:

[14] to behave kindly with the people of conquered localities, to guarantee their protection, to provide them with moral and material security against outside enemies, to grant them full liberty in religious matters, to yield them fiscal facilities ${ }^{24}$.

[15] In various eras and settings, this pursuance of 'conciliation' recurs like a motto: in lateeighteenth-century Aegean islands ${ }^{25}$, in nineteenth-century Montenegro ${ }^{26} \ldots$ And such a keynote of Ottoman provincial policies is what, in Safvetī Paşa's words, verbal orders allow to keep up.

[16] This effectiveness of non-written words, moreover, goes beyond the only register of order-giving. Rather, the use of orality by provincial administrators spans the whole of their repertoire of action. Oral is the report that the governor of Cyprus requires from a local Christian notable (koca-

${ }^{21}$ Ibid:: 'tezkere ve karantīna usūllerine ziyāde dikkat ve atalar ahālisine ba'zı vesāyā-yı lisāniyye ile i'tā-yı istimālet olunması'.

${ }^{22}$ Redhouse 1890: 1631 ('lisān: 1. The tongue. 2. Any tongue-shaped thing. 3. A language, dialect, idiom. 4. A spokesman.')

${ }^{23}$ Phrases using the word in Ottoman Turkish testify to this point (ibid.): 'lisāna almak: To speak about; lisāna getirmek: To make be talked about in an evil manner; lisāna gelmek: To become talked about in an evil manner', and also the adverb 'lisānen: By tongue; by word of mouth, orally.'

${ }^{24}$ illgürel 2001: 362 ('Fethedilen yerlerin halkına iyi davranma, onları himaye etme, dış düşmanlara karşı can ve mal güvenliği sağlama, dinî konularda serbestiyet verme, vergi hususunda kolaylık gösterme'.) See also Lowry 2003: 68.

${ }^{25}$ Parmaksızoğlu 1977: 130 ('istimālet ile mu'āmele.')

${ }^{26}$ Reinkowski 2005: 238. Also see Reinkowski 2003: 245. 
Citation : Aymes, Marc (2007) 'The Voice-Over of Administration: Reading Ottoman Archives at the Risk of III-literacy',

European Journal of Turkish Studies, Thematic Issue $N^{\circ} 6$, III-literate Knowledge, URL: http://www.ejts.org/document1333.html

To quote a passage, use paragraph (§).

başı), Ābeydo, and from the Lefkoşa 'register inspector' (defter nāzırı) Hüseyin Ag̉a, following their investigations as to archaeological remains recently unearthed in the port-city of Tuzla (Larnaca) ${ }^{27}$. Oral are the 'conversations' that Safvetī Paş encourages his subordinates to engage in with the kocabaş/s of the islands, so that they 'advise [their] fellow countrymen' to give up any consular protection $^{28}$. Oral again are the explanations that the governor sends one of his agents to provide to the British consul Niven Kerr concerning certain affairs: 'he had sent Haggi Kirghei, one of the Kogia Baschis, to explain to me verbally the measures necessary to be taken' ${ }^{29}$. And oral are the discussions that the governor himself holds with European consuls when coming to Larnaca:

[17] An ancient usage, to be ascertained from the correspondence of MM. the Consuls of Cyprus at Larnaca, is that each year in October the Governor of the island comes to be paid a visit by the Consuls, and to verbally terminate with them the matters on which some misunderstanding would have occurred during the year, or whose solution would remain in abeyance ${ }^{30}$.

[18] Consular archives are thus sprinkled with incidents, petty or serious, smoothed over through concerted sweet talk. On May 10, 1822, clashes occur between people from Larnaca and some 'foreign soldiers' (sent from other Ottoman provinces, mainly Egypt and Southern Anatolia, to prevent troubles in relation with the outbreak of the Hellene rebellion in mainland Greece): 'Their leaders immediately rushed to me, I received them for a conference at my place, soon we agreed that nobody could have prevented this brawl from happening, and everybody calmed down ${ }^{\prime 31}$. In July

${ }^{27}$ BOA, I.DH 829, round robin of the Cyprus council (n.d. [ May-June 1840]): 'keyfiyetiñ bu vechile cānib-i 'ācizāneme şifāhen ifādeleri.'

${ }^{28}$ BOA, I.DH 11188, copy of Safvetī Paşa's instructions to the administrators of the small islands adjoining Rhodes (n.d. [ Receb 1265/May-June 1849]): 'kocabaşılarla sohbet arasında sıra düşdükce 'bu ecnebī himāyetinde olan hemşehrīleriñize nasīhat itseñiz-de [...]'.

${ }^{29}$ PRO, FO 78/621, vol. 2, f. 89 oo (Kerr to Canning, $n^{\circ} 2$, 4 April 1845; copy annexed to despatch $n^{\circ} 6$ from Kerr to Aberdeen, 6 May 1845).

${ }^{30}$ MAE, CCC, Larnaca, vol. 17, f. 284 (Guillois to Sebastiani, $n^{\circ}$ 10, 25 October 1831): 'Un ancien usage qui doit être constaté par la correspondance de MM. les Consuls de Chypre à Larnaca, amène chaque année au mois d'octobre le Gouverneur de l'île qui vient recevoir la visite des Consuls, et terminer verbalement avec eux les affaires qui dans le cours de l'année auraient donné lieu à quelque mésintelligence ou qui seraient encore en suspens.'

${ }^{31}$ MAE, CCC, Larnaca, vol. 16, f. 290 oo-291 (Méchain, n 22, 3 April 1822): 'Les chefs sont aussitôt accourus, je les ai reçus chez moi en conférence, il a bientôt été convenu que ni eux ni moi nous n'avions pu prévenir cette rixe et tout s'est apaisé.' 
Citation : Aymes, Marc (2007) 'The Voice-Over of Administration: Reading Ottoman Archives at the Risk of III-literacy', European Journal of Turkish Studies, Thematic Issue $N^{\circ} 6$, III-literate Knowledge, URL: http://www.ejts.org/document1333.html

To quote a passage, use paragraph (§).

the same year, 'bands of insurgents' wreak terror in the population, threatening to attack the people of Larnaca: another 'conference' takes place, this time with 'Salik Bey, general of the Egyptian troops', and the captain of a French frigate currently moored before the city, de Rigny ${ }^{32}$. Such frequent face-to-face intercourse is why, the French consul boasts, he could establish an 'intimate relation' with the 'Egyptian' commander Sālik Beg ${ }^{33}$. An intimacy he also tries to bring about with the governor of the island Küçük Mehmed Paşa, 'the Barbarian who has been depopulating and ruining it for two years' ${ }^{34}$ :

[19] The ambassador has invited me to maintain the Governor's benevolence towards me. This I have striven to manage and since several conferences I had with him, our relations are the best one could hope to establish with such a temper indeed $^{35}$.

[20] In each of these occurrences, the search for an oral compromise points to the certainty that writing will not suffice. The back-and-forth nature of such verbal engagements also testifies to the variety of channels and intermediaries that provincial administration could harness - a point to which one shall get back further on. For administrators confronted with an unruly province teeming with conflicts, ambitions and secrets, only talk is suffused with the necessary sweetness to have their orders obeyed, their routines smoothed, their knowledge grounded.

\section{Administering Vowels: Authorized Words Only}

[21] Orality, contrary to what was suggested above, cannot be understood as a sheer lining that repeats the written order: rather, it shelters singular forms of knowledge, a knowledge by word of mouth whose inflections paper cannot hold.

\footnotetext{
32 Ibid., f. 297 et oo (Méchain, $n^{\circ} 25$, 18 July 1822).

${ }^{33} \mathrm{Ibid}$., f. 311 (Méchain, $\mathrm{n}^{\circ}$ 28, 25 September 1822): 'Je m'appuie beaucoup de [sic] l'influence de Salik Bey, commandant en chef des troupes de Mehemet Ali pacha, avec qui j'entretiens une liaison intime.'

${ }^{34}$ Ibid.: 'le Barbare qui la dépeuple et la ruine depuis deux ans.'

${ }^{35}$ Ibid.: 'L'ambassadeur m'a invité à me soutenir moi-même dans la bienveillance du Gouverneur. J'y ai travaillé et en effet, depuis plusieurs conférences que j'ai eues avec lui, nous sommes aussi bien que l'on peut l'être avec un pareil caractère.'
} 
Citation : Aymes, Marc (2007) 'The Voice-Over of Administration: Reading Ottoman Archives at the Risk of III-literacy',

European Journal of Turkish Studies, Thematic Issue $N^{\circ} 6$, III-literate Knowledge, URL: http://www.ejts.org/document1333.html

To quote a passage, use paragraph (§).

[22] The phrase 'feth ü kırā'at', announcing that an order has been 'unfolded and pronounced' before provincial grandees, tells much more than already stated in this respect. At first sight, these terms might refer to any ordinary act of reading, describing it in its banal materiality: the governor unseals (feth), then reads aloud (kırāat) the written letter he has been addressed. Yet a closer examination reveals access to less run-of-the-mill forms of reading. 'Feth' is not just about unsealing: it also relates to the idea of a quasi-divine elucidation ${ }^{36}$. And 'kırā'at' is no ordinary diction, for it unavoidably evokes the recitation of sacred words, of the Kur'an known by heart ${ }^{37}$ :

[23] Recitation (qira'a) is the mode in which the Quran figures in ritual life, and a recitational style also structures the articulation of basic sharia principles in legal practice. [...] All this was especially crucial in connection with the sacred text and similarly treated authoritative texts, including fiqh manuals and hadith reports, which partook of the privileged quality of the recited word. When textual authority, involving the restoration of an original voiced presence, was at stake, recourse was had to the faithful recitational reproduction, directly from memory or, secondarily, by reading the matn [original text] in question aloud ${ }^{38}$.

[24] In other terms, letters have no real effectiveness if confined to the silence of writing: they always need the backup authority of lively utterances.

[25] To be sure, documents used by Ottoman provincial administrators would not be read as 'figh manuals and hadith reports': one needs to stress that there always is a 'situational relationship between language and type of text, whether religious or secular' (Fortna 2001: 34). Yet the semantic parallel between these two uses of kirāat is no mere play on words either: while perusing the archives from the Tanzimat period, one is struck by the administrators' insistence on making their rule

${ }^{36}$ Redhouse 1890: 1364 ('feth: 1. An opening. 2. A beginning, commencing. 3. A conquering; conquest, victory. 4. God's opening or bestowing a thing in His providence; a gift of grace, a Providence; assistance of any form. 5. A solving, elucidating a difficulty; solution, elucidation [...]').

${ }^{37}$ Ibid.: 1444 ('kırā'at: 1. A reading. 2. A reading or reciting the Qur'an in a solemn or artistic manner. 3. (pl. kırāāt) A special method of pronouncing each word in the Qur'an'). Similar religious connotations also permeate the word 'telkin: A communicating orally; especially, a teaching a novice to repeat the articles of the faith of Islam, or, a prompting the articles of faith to a deceased person, that he may have answer for the questioning angels' (ibid.: 588).

${ }^{38}$ Messick 1993: 22 and 26. Though it relates to a specific locality (the lbb area in Southern Yemen, where the Shafiî rules supreme), the author's assertion may be considered a yardstick for studying other parts of the Ottoman Muslim world: see Paret 1986. 
Citation : Aymes, Marc (2007) 'The Voice-Over of Administration: Reading Ottoman Archives at the Risk of III-literacy',

European Journal of Turkish Studies, Thematic Issue $N^{\circ} 6$, III-literate Knowledge, URL: http://www.ejts.org/document1333.html

To quote a passage, use paragraph (§).

acknowledged aloud. Suffice it to quote in what terms the members of the Cyprus council report on Safvetī Paşa's visit to Lefkoşa in early June 1849:

[26] We humbly gained knowledge of the mercy-laden tenor of the firman, exalted sign of justice, which was read and chanted aloud with all perfect respect and observance, concerning the announcement that His Asaf-like compassionate Excellency has been appointed as marshal endowed with illustrious feats; and [we gained knowledge] more particularly of the decrees and verbal orders that were henceforth presented with honour by His comfort-lavishing Excellency ${ }^{39}$.

[27] 'Read and chanted': such a phrasing calls for emphasis. Both terms indeed convey precise connotations: 'tilāvet' refers to 'reading or chanting aloud a considerable portion of the scriptures'; 'tertil' is about the teeth's being even and regular, but also signals a clear and distinct enunciation, and, above all, 'the slowest in time of the three rates of reading or chanting the Qur'an' ${ }^{40}$. Clearly then, the terminology encountered here points to the articulation of the sacred.

[28] From this one may deduce that the mid-19th-century Ottoman officialese intimately relates to the verbal economy of canonical Islamic traditions. This relation thickens even more when one recalls another phrase used as a quasi-maxim by the period Ottoman administrators. Whenever an order is sent or received to a province of the Empire, it prompts a formulaic commitment to respect its regulations, which often contains the phrase 'to the letter' (harf be-harf). Thus in the report sent by the governor of Cyprus Ibrāhīm Edhem Paşa on December 4, 1844: 'great zeal and endeavour are to be deployed so that the eminently distinguished decrees be enforced to the letter ${ }^{41}$. Or in this document by another provincial governor, dated October 4, 1845: 'it goes without saying that no deficiency or flaw will be permitted regarding the sacred duty to enforce and execute the sublime order to the

${ }^{39} \mathrm{BOA}, \mathrm{I.DH} 11188$, round robin signed by the main authorities of the island (but the governor, and in the absence of the local judge) (15 Receb 1265 [6 June 1849]) (emphasis added): 'bu kere zāt-ı merāhim-simāt-ı āsafāneleriniñ i'lān-ı me'mūriyet-i celīli-I-menkabe-i müşīrāneleri hakkında kemāl-i ādāb ü tebcīl ile tilāvet ü tertīl buyrulmuş olan fermān-ı ma'delet-nişān-ı 'ālī me'āl-i merāhim-iştimālinden ve husūsıyla müte'ākıben şerefsunūh buyurılan emr ü irādāt-ı şifāhiyye-i veliyyi-n-nu'malarından ma'lūm-ı bendegānemiz olmuş.'

${ }^{40}$ Redhouse 1890: 586 and 529 respectively. Compare Paret 1986: 131: 'Dans la récitation des 'lecteurs' de métier [...] on distingue un mouvement lent et posé, un rapide et un modéré (tartīl ou tahkīk - hadr - tadWir)'.

${ }^{41}$ BOA, A.MKT 19/7, report ('arīza) by İbrāhīm Edhem Paşa (23 Zī'l-ka'de 1260 [4 December 1844]): 'ahkām-ı ma'âlī-ittisāmınıñ harf be-harf icrā-yı dā’imiyyesine savb-ı 'abīdānemden bezl ü sa'y iktidār olundığı.' 
Citation : Aymes, Marc (2007) 'The Voice-Over of Administration: Reading Ottoman Archives at the Risk of III-literacy',

European Journal of Turkish Studies, Thematic Issue $N^{\circ} 6$, III-literate Knowledge, URL: http://www.ejts.org/document1333.html

To quote a passage, use paragraph (§).

letter' ${ }^{42}$. Later, in 1847, an order sent to several provincial governors reads: 'a set of regulations having been laid down on these matters, the appended decrees should be considered as laws in force and implemented ceaselessly to the letter, and no violation should occur' ${ }^{43}$. And, in his instructions to the administrators of the small islands adjoining Rhodes, Safvetī Paşa also stresses that 'attention should be duly paid to the herewith enclosed decrees being enforced to the letter' ${ }^{44}$. How to understand such an emphasis? Is the 'harf be-harf phrase more than a void formulaic leitmotiv?

[29] Following up on the pious semantics pinpointed above, one may look for a possible answer in the field of certain Islamic legal traditions. 'To the letter', indeed, counts among the precepts regulating the transmission of prophetic traditions (hadis) in the Ottoman world at large. According to the jurist al-Shafii', 'an authoritative relayer of hadith should be 'capable of transmitting the hadith letter for letter [bi-hurufihi] as he heard it'.' (Messick 1993: 26). This coincidence might not be more than that, and one should ward off the temptation to use it in any explanatory way: for, it is the Hanafi school, not Shafi'ism, that constitutes the main official legal authority in the Ottoman Empire, and it is not sure that the idea of reading 'to the letter' is common to both ${ }^{45}$. Yet, although uncertain, this possible influence of Sunni theological precepts on administrative discourse obliges to take 'harf be-harf' seriously, and not just as a superficial rhetorical effect: hackneyed as it sounds, the phrase expresses (among many others ${ }^{46}$ ) the eagerness of Ottoman administrators to make the letter of reforms heard in the provinces.

[30] And one must add: all the letter - that is, a vocalized letter. Since, as Brinkley Messick has stressed:

${ }^{42}$ A.MKT 28/67, 'arīza signed by 'Es-seyyid 'Abdüllah' (2 Şevvāl 1261 [4 October 1845]): 'irāde-i seniyyeniñ harf be-harf infāz ü icrāsı ferīza-ı matlūbesinde tecvīz-i kusūr ve fütūr olunmayacaǵı der-kār.'

${ }^{43}$ BOA, A.MKT 104/104, draft of a note (kā'ime) intended for several provincial governors, including the governor of Cyprus (n.d. [ 1847]): 'ol-bābda bir kıt'a nizām-nāme kaleme alınub ahkām-ı mündericesi düstūrü--'amel tutularak her tarafda 'alā-l-devām harf be-harf icrāsıyla hilāfı hālāt vukū'a götürülmemesi.'

${ }^{44}$ BOA, I.DH 11188, copy of Safvetī Paşa's instructions to the administrators of the small islands adjoining Rhodes (n.d. [ Receb 1265/May-June 1849]): 'işbu ta'līmātıñ [...] münderic oldıg̉ı ahkāmıñ harf be-harf icrāsIna dikkat [...] oluna.'

${ }^{45}$ At least stakes sound similar - after Paret 1986: 130: 'En lisant le ductus consonantique officiel, le 'lecteur' gardait toujours la liberté de choisir parmi un certain nombre d'autorités.'

${ }^{46}$ See Aymes forthcoming: chapter 2. 
Citation : Aymes, Marc (2007) 'The Voice-Over of Administration: Reading Ottoman Archives at the Risk of III-literacy', European Journal of Turkish Studies, Thematic Issue $N^{\circ} 6$, III-literate Knowledge, URL: http://www.ejts.org/document1333.html

To quote a passage, use paragraph (§).

[31] As it usually appears on the page, Arabic script consists of strings of unvoweled consonants. The act of voweling, whether by marking in the vowel signs over and under the consonantal string or by voicing them in recitation, is an interpretive act, lending the script a particular significance in the process. This is important because written texts often allow alternative vowelings. While script preserves a string of consonants, recitation units consonants and vowels, enabling the production and reproduction of a whole. Given the nature of its script conventions, there is an identifiable physical loss in 'reducing' something in Arabic to writing. In comparison with a fully vocalized 'word', a written text can be considered an incomplete consonantal fragment. Preserved in its voweled-consonant recitational form, by contrast, a memorized text is one that has been embodied complete. (Messick 1993: 26$)^{47}$

[32] In that sense, 'to the letter' is far from being a hollow refrain in Ottoman archives: it rather points to an administration haunted by invisible vowels, and anxious not to let them slip through the net of writing. And it brings back the elucidation of 'feth': for this word, beside its already mentioned meanings, also refers to the vocalized pronunciation of certain consonants ${ }^{48}$. 'To the letter' hence needs to be read, quite precisely, to the letter.

[33] Further readings allow to refine this analysis. Let us first consider a collection of papers held by a census officer sent to Cyprus in 1831-32, Mehmed Es'ad Beg, which contains copies of the various orders he had been addressed. On top of one of these, a short note has been added by a scribe of Mehmed Es'ad Beg's:

[34] This is a copy of the firman about certain matters, aiming to prevent estates and properties from falling into the hands of foreigners, which is contrary to the capitulations; having formerly been addressed to the defunct [governor of the island $\left.{ }^{49}\right]$, it could not be pronounced, and remained in abeyance until by appointment our coming was decided; since it relates to questions that match the letter of

${ }^{47}$ These matters also have been dealt with (regarding $10^{\text {th }}$ - $13^{\text {th }}$-centuries madrasas) by R. Bulliet (1994: 1322), and (as concerns Marrakesh in the 1920s and 1930s) by D. Eickelman (1978).

${ }^{48}$ Redhouse 1890: 1364 ('feth: [...] 6. A pronouncing a consonant with the vowel a or e following it in the same syllable').

${ }^{49}$ Namely Es-seyyid Halīl Efendi, suddenly deceased on December 28, 1831 (MAE, CPC Turquie, Consulats divers, vol. 1, f. 293: Bottu to Sebastiani, $n^{\circ} 3$, duplicata, 2 January 1832). Due to the vacancy of his post, "local authorities' conferred the title of 'temporary governor' on Mehmed Es'ad Beg himself upon his arrival to Cyprus (ibid., f. 300 vo: Bottu to Sebastiani, n 10, 6 January 1832). 
Citation : Aymes, Marc (2007) 'The Voice-Over of Administration: Reading Ottoman Archives at the Risk of III-literacy',

European Journal of Turkish Studies, Thematic Issue $N^{\circ} 6$, III-literate Knowledge, URL: http://www.ejts.org/document1333.html

To quote a passage, use paragraph (§).

instructions I hold in my hand, it has been pronounced along with the sacred orders I have been entrusted with ${ }^{50}$.

[35] Here, as was already the case above, oral performance is what puts an end to the 'abeyance' of written letters. And the present quotation allows us to push this conclusion a bit further: what had prevented the order formerly addressed to the governor of Cyprus from coming into force is the very fact that he could not be pronounced. There is no possible implementation without articulation.

[36] Then there is a round robin signed by the Lefkoşa council, in spring 1840, regarding the archaeological remains recently unearthed in Tuzla. As already mentioned earlier, it states that the kocabaşı Ābeydo and the Lefkoşa 'register inspector' Hüseyin Ag̉a have been commissioned by the governor to report orally on that matter. Yet parallel information also has been sent to him in a written form, by his own 'representative' (vekīl) in Tuzla. Now here is how the Lefkoşa governor sums up the whole case before the council:

[37] Their [Ābeydo and Hüseyin Aġa's] oral report to my humble side concerning the situation has allowed to ascertain the accuracy [isbāt] of the note sent by the aforementioned humble servant of yours to my insignificant side ${ }^{51}$.

[38] What appears here is that a hierarchy of proof (isbāt) submits the letters laid down on paper to the test of an oral corroboration. Emulating the kadi who grants a prevalent value to oral testimony as compared with any written document, here the administrator gives primacy to uttered reports over paper records.

[39] One more quotation. This time it concerns litigation over unsettled debts that local Church authorities owe to a former consular representative of Naples, Antonio Calliméry. Having been given the case, in 1835 the French consul Vasse de Saint Ouen seizes the opportunity of the

${ }^{50}$ BnF, Suppl. turc $1042 \mathrm{f}$. 19 №, copy of an order to the governor of Cyprus Es-seyyid Halīl Efendi and other local authorities (evāsıt Şevvāl 1240 [29 May- 8 June 1825]): 'Müste'min 'uhdelerinde olan arāzi ve emlākıñ mug̉āyir-i 'ahd-nāme olmag̉la mukaddemce men'i içün müteveffā tarafına gelmiş ba'zı husūsa dā’ir kırāat olunamayarak ber muktezā-yı me'mūriyet gelmemize tevkīf olunmuş yedimde olan ta'līmāt-nāmeye mutābık bir mevādd oldıġından hāmil oldıg̉ım evāmir-i şerīfe ile berāber kırā'at olunmag̉la sūret-i fermānıdır.'

${ }^{51}$ BOA, I.DH 829, round robin of the Cyprus council (n.d. [ May-June 1840]): 'keyfiyetiñ bu vechile cānib-i 'ācizāneme şifāhen ifādeleri vekīl-i mûmāileyh kullarınıñ savb-ı kem-terāneme tevārüd iden şukkalarını isbāt eylemiş.' 
Citation : Aymes, Marc (2007) 'The Voice-Over of Administration: Reading Ottoman Archives at the Risk of III-literacy',

European Journal of Turkish Studies, Thematic Issue $N^{\circ} 6$, III-literate Knowledge, URL: http://www.ejts.org/document1333.html

To quote a passage, use paragraph (§).

governor's annual visit to Larnaca and brings it to his attention. He produces Calliméry's credentials before him: 'These documents having been presented to the Governor's eyes, examined by him, and read aloud by the kocabaş/s, they were considered genuine and authentic ${ }^{52}$. Again, here, a written proof needs the authority of a voice to retrieve its validity. It confirms the existence of an intimate connection between orality and authenticity.

[40] Little by little one can thus delineate the features of Ottoman administration as a vocalized one. To this extent, silent and voiceless as the remains of the Ottoman world may be today, the archives of such an administration should be understood as essentially oral. Namely, archives that need an articulate reading to retrieve their full authority; archives that must be put to the test of loud declamation (resembling what Gustave Flaubert used to call 'l'épreuve du gueuloir') lest they raise suspicions of misunderstanding. For all the 'paper-pushing routine' they prompted, then, the 'reorganizations' undertook by the Ottoman administrators mainly brought about a profusion of speech acts. These voices got muffled, most of them completely mute now, once stored in archives. But any attempt to decipher the latter needs to revive these oral remnants.

\section{Vertigophony}

[41] III-literacy, though, is not only about letters failing to retrieve the compromising tones and fine vocalizations that administrators crucially needed. Riddled with embarrassing blanks and silences, Ottoman archives are also rife with bulges and surges, hollers and splutters that these very same administrators contrive to jettison.

\section{Pricking Up One's Ears}

[42] First one needs to better understand by what means Ottoman officials manage to gain and broaden their knowledge about the place they are in charge of. In a world where the prime role is conferred to words uttered, the work of administrators first and foremost requires to prick up one's

${ }^{52}$ MAE, CCC, Larnaca, vol. 18, f. 393 vo (Vasse de Saint Ouen to de Broglie, n² 24, 31 October 1835): 'Ces titres mis sous les yeux du Gouverneur, examinés par lui, lus à haute voix par les Kodja bachis, ont été trouvés bons et authentiques.' 
Citation : Aymes, Marc (2007) 'The Voice-Over of Administration: Reading Ottoman Archives at the Risk of III-literacy',

European Journal of Turkish Studies, Thematic Issue $N^{\circ} 6$, III-literate Knowledge, URL: http://www.ejts.org/document1333.html

To quote a passage, use paragraph (§).

ears. As a matter of fact the talent of aural acuity, signaled by various forms of the same lexical root $[s-m-]$, is a commonplace idea in the documents circulating among them:

[43] 'with respect to the information minutely collected and heard, publicly and secretly, by the humble servant that I am since my insignificant arrival to the aforementioned island $[\ldots]^{53}-$ things have also been heard from people who come from Karpās, Bāf other places ${ }^{, 54}-$ it has been heard that unacceptable occurrences, contravening this order [of the Tanzimat] and the exalted wish [of the sultan], take place in various places and for multiple reasons ${ }^{, 55}$ - 'according to what has been heard, in the aforementioned island there are people who ask and seize free food for themselves and their beasts ${ }^{, 56}-$ it has been heard that this man, $[\ldots]$ driven by the desire to become archbishop, might have proclaimed on his own initiative his appointment to this office ${ }^{, 57}$.

[44] First, then, listening to what has been said or done, and collecting hearsay: that is what the administrator's job consists in.

[45] The instructions addressed in 1847 to a special commissioner sent to Cyprus, 'Abdülvahhāb Efendi, testify to this point with a particular clarity, and deserve lengthy quotation:

[46] Word has it that if an end was put, with His exalted intercession, to the scourge of locusts invading the island, it would help the people of the island to retrieve their estates, properties and other goods that have fallen into other [foreigners'] hands. Ascertain the truth on this matter [...], and get to the bottom of it, so

${ }^{53}$ BOA, I.MVL 1317, report by the governor of Cyprus Hācı Mesrūr Ag̉a (7 Receb 1261 [12 July 1845]): 'cezīre-i merkūmeye vürūd-ı çākerānemden-berü hafī ve celī vāki' olan tedkīkāt ve mesmū'āt-ı 'abīdāneme nazaren.'

${ }^{54}$ BOA, I.MVL 352, report ('arīza) signed by the governor of Cyprus 'Mehmed Tal'at' and 'Es-seyyid Mustafa', colonel in charge of public order in the island (7 Safer 1257 [31 March 1841]): 'Karpās ve Bāf ve sā'ir ba'zı mahallerden gelen adamlardan dahū böyle gizlice şeyler istimā‘ eylemiş.'

${ }^{55}$ BOA, A.MKT 107/33, draft of a memorandum sent to several provincial governors (n.d., two distinct dates overleaf: 17 Muharrem 1264 [25 December 1847] and 2 Safer 1264 [9 January 1848]), regarding some contraventions to the Tanzimat rules: 'ba'zı mahallerde dürlü sebeblerden tolayı bu nizām ve matlab-ı 'ālīniñ hilāfı olarak vukū'āt-ı ġayr-i merziyye mesmū' olması.'

${ }^{56}$ BOA, A.DVNS.MHM.d 257, n 52, order to the authorities of Cyprus (evāhır Şa'bān 1263 [4-12 August 1847]): 'istimā' oldugiuna göre cezīre-i mezkūrede ba'zı kesān ahāliden meccānen yem ve yiyecek mutālebe ve ahz etmekde.' (A draft of this text is to be found in BOA, A.DVN.MHM 4/50.)

${ }^{57}$ BOA, A.MKT 204/77, draft of a note (şukka) sent to Safvetī Paşa (n.d., date overleaf: 19 Receb 1265 [10 June 1849]): 'gūyā bu adam [...] kendüsini baş piskopos itmek dā'iyesiyle hôd-be-hôd me'mūriyetini i'lān ve icrā itmiş oldukları istimā' olunmuş.' 
Citation : Aymes, Marc (2007) 'The Voice-Over of Administration: Reading Ottoman Archives at the Risk of III-literacy',

European Journal of Turkish Studies, Thematic Issue $N^{\circ} 6$, III-literate Knowledge, URL: http://www.ejts.org/document1333.html

To quote a passage, use paragraph (§).

that no doubt or complications remain possible; elucidate the true situation with the necessary registers, and make it known ${ }^{58}[\ldots]$.

[47] Word has it that, on account of what is called country expenses, four hundred thousand piastres or so are to be part of the annual tax. Since one needs to ascertain what are the expenses in question, a detailed register has to be sent, and it is also necessary to determine whose expenses they are. Deploy your zeal, in the aforementioned way, on these matters as well ${ }^{59}[\ldots]$.

[48] Word has it that the population inspector Hācı Hüseyin Aġa, who is a member of the Lefkşa council, has indulged in improper behaviour. If in truth the maintenance of this man in office causes damage and impropriety, devote due attention to his being dismissed from the council and to reporting this matter here [in Istanbull ${ }^{60}$.

[49] 'Word has it that...': pivotal in this leitmotiv is the word 'rivāyet', the exact meaning of which deserves minute examination. First it is a vague rumour, a narrative whose origin remains unknown ${ }^{61}$. Yet the term soon takes on more assertive tones: it can refer to 'the 'oral transmission' of a particular text or texts through recitation', as performed by students in religion during their curriculum (Messick 1993: 22); it can also be 'a decision handed down from some legist of reputation'62; or 'a variant reading of a word of the Qur'an, handed down by a pupil of one of the masters of reading' ${ }^{\prime 63}$. In short, what first sounded like mere hearsay ends up smelling like orthodoxy: it conveys words endowed with a latent authority. The ability to ratify this authority is precisely what the Ottoman govern-

${ }^{58}$ BOA, I.MVL 2240, instructions to 'Abdülvahhāb Efendi (n.d. [ spring 1847]): 'yed-i āhara geçmiş bulunan emlāk ü arāzi ve sāireniñ cezīreye müstevlī olmuş olan çekirge beliyesiniñ bi-havlihi te'ala def'inde tahlīsi husūsuna ahāli-i cezīre muktedir olacakları rivāyetine göre bu husūsuñ [...] bir gūne ilişik ve şübhe götürür yeri kalmayacak sūretde sıhhatını tahkīk birle lāyıkıyla zāhire ihrāc iderek keyfiyet-i hakīkiyyelerini defātir-i lāzımesiyle ìzāhen iş'ār eyleye.'

${ }^{59}$ Ibid.: 'işbu virgünüñ içinde dört yük g̉urūş kadar akçe masārif-i memleket nāmıyla sarf olunan şey oldığı rivāyet kılınmakda olmasıyla bunuñ dahī ne-makūle masraf oldığı bilinmek içün müfredāt defteriniñ irsāl kılınması ve-I-hāletü hazihi o misillü masraf ne-tarafdan görülmekde idügi dahī tahkīk kılınması lāzımeden olmag̉la bu husūslara dahī ber vech-i muharrer himmet eyleye.'

${ }^{60}$ Ibid.: 'Lefkoşa meclisi a'zāsından nüfūs nāzırı Hācı Hüseyin Aġa'nıñ ba'zı mertebe uyǵunsuzluǵı rivāyet olunmakda oldıg̉ından fî---hakīka bu adamıñ hidmetde bekā ve istihdāmı muzırr ve uyġunsuz oldığı hālde meclisden çıkarılması ve keyfiyetiñ bu cānibe bildirilmesi husūslarına dikkat eyleye.'

${ }^{61}$ Redhouse 1890: 991 ('rivāyet', first meaning of the word: 'A narrative; a legend; a tradition').

${ }^{62} \mathrm{Ibid}$. ('rivāyet', second meaning of the word).

${ }^{63} \mathrm{lbid}$. (third meaning of the word). Which is quite exactly, according to R. Paret, one of the meanings of the word 'kırā'at': 'la lecture spéciale d'un seul mot ou d'un passage kur'ānique déterminé (kirā'a, pl. kirāāāt = variante)' (1986: 129). 
Citation : Aymes, Marc (2007) 'The Voice-Over of Administration: Reading Ottoman Archives at the Risk of III-literacy', European Journal of Turkish Studies, Thematic Issue $\mathrm{N}^{\circ} 6$, III-literate Knowledge, URL: http://www.ejts.org/document1333.html

To quote a passage, use paragraph (§).

ment expects from its provincial agents - as the requirements listed in 'Abdülvahhāb Efendi's case illustrate above. Wherever in the 'well-protected domains' they stand, the sultan's servants have to show a relentless perspicacity. A note sent to several of them in late 1847 and early 1848 encapsulates such a maxim in the most imperious manner:

[50] Supposing the things that have been heard adjoin the truth, they [the provincial governors] will be held accountable for having not understood and signalled it in due time ${ }^{64}$.

[51] As above ('ascertain the truth', 'elucidate the true situation', 'if in $\operatorname{truth}^{165}$ ), one perceives here that the repertoire of action incumbent on provincial administrators revolves around an eagerness to steep sheer rumours in an authorized truth.

[52] This repertoire, one may add, is a double-edged one, since it also signals the necessity to circumscribe the domain of what 'causes damage and impropriety' ${ }^{66}$. The constitution of a local knowledge by Ottoman provincial administrators aims not only at setting up the rules of their authority, but also at ensuring the due respect of these rules. Hearsay hence becomes a means to ascertain the provincials' loyalty - or, conversely, to single out and repress seditious acts. Such is the precept one can read in Safvetĩ Paşa's instructions to his subordinaires, in 1849:

[53] If vagabonds come to the island for no reason and, whether they hold a [passage] permit or not, cause suspicion by their condition, behaviour and moves, they will be granted no permission to wander across the island; beside, if they insist on setting off on an excursion [towards the interior of the island], and if their words denote some bad intention, [...] they should be sent to Rhodes. [...] Moreover, it has been heard that some Greeks [Yūnänlü] have come to the islands and talk in a way that may trouble the minds of the subjects; if somebody of this kind comes, holding the mandatory passport and health document in his hand, and reportedly talks in an unsettling and seditious manner while on an excursion, this man should be summoned to the [local] council and confronted with those who heard his

${ }^{64}$ BOA, A.MKT 107/33, draft of a memorandum sent to several provincial governors (n.d., two distinct dates overleaf: 17 Muharrem 1264 [25 December 1847] and 2 Safer 1264 [9 January 1848]): 'işidilen şeyler mukārini sıhhat oldıg̉ı hālde vaktiyle añlayub 'arz ü inhā olunmadıġından tolāyı me'sūliyet üzerlerinde kalacaǵı.'

${ }^{65}$ BOA, I.MVL 2240, quoted above: 'sıhhatını tahkīk', 'keyfiyet-i hakīkiyyelerini îzāhen', 'fî-l-hakīka.'

${ }^{66}$ Ibid.: 'muzırr ve uyġunsuz.' 
Citation : Aymes, Marc (2007) 'The Voice-Over of Administration: Reading Ottoman Archives at the Risk of III-literacy',

European Journal of Turkish Studies, Thematic Issue $N^{\circ} 6$, III-literate Knowledge, URL: http://www.ejts.org/document1333.html

To quote a passage, use paragraph (§).

words; a journal should be set up by the council and sent to us, and the man in question should also be escorted toward us ${ }^{67}$.

[54] Clearly enough, this document outlines the modus operandi deployed by period provincial administrators. Even more than a person's 'condition, behaviour and moves', their perspicacity tracks down 'words' and 'talk.' Even more than the individuals themselves, it is their utterances that have to be prevented from wandering the province.

[55] The double warning that Safvetī Paşa has issued as a supplement to his instructions corroborates this vision:

[56] Such measures should not be applied to any passer-by, but only to vagabonds who are causing suspicion: as to those who are not, and who do not hold any permit, one should deem it sufficient to send them back [to their place of ori$\operatorname{gin}]^{68} \cdot[\ldots]$

[57] Careful heed should be taken of this: these measures are not to be applied to anybody who starts speaking, but to those Greeks and other vagabonds whose words would cause sedition among the subjects ${ }^{69}$.

[58] One can thus better understand the relevance criteria that underpin the Ottoman approach to hearsay: in the immensities of language, some words require the authority to intervene and to pin them down to a particular meaning; others do not. Hence administrators do not need to pay a similar attention to all the utterances that run through the province: to some they must impart gravity; others count for nothing, and can be dismissed as frivolous - as is the case for these vagabonds who, since they arouse no suspicion, are simply sent back where they came from.

${ }^{67}$ BOA, I.DH 11188, copy of Safvetī Paşa's instructions to the administrators of the small islands adjoining Rhodes (n.d. [ May-June 1849]): 'işsiz ve maslahatsız olarak gerek tezkerelü ve gerek tezkeresiz olsun cezīreye gelen serseri makūleleriniñ hāllerinden ve tavr ü hareketlerinden şübhe olundığı hālde cezīreye çıkub gezmesine ruhsat virilmeyeceginden başka hārice çıkmag̉a ısrār ider ve kelāmlarından bir fenālık añlaşılur ise [...] Rodos'a irsāl oluna [...] birde ve Yūnānlü'den ba'zıları cezīrelere gelüb re'āyānıñ zihniyetini bozacak sözler söyledikleri işidilmekle o makūle bir kimse gelür ve usūli vechile yedinde pasāport ve sıhhiye kāġıdı olarak hārice çıkarak öyle yolsuz ve fesādlü sözler söyledigi işidilür ise o adamı meclise getirüb ve söyledigi sözleri işidenler ile yüzleşdirüb meclisde bir kıt’a jūrnāli tanzīm ile tarafımıza irsāl ve ol adam dahī yanına adam terfikiyle tarafımıza isbāl oluna.'

${ }^{68}$ Ibid.: 'bu sebeble rāst gelen adam gönderilmeyüb bu sūret fakat kendüsünden şübhe olunan serseri makūlesi-hakkında olub öyle şübhe olunmayan ve yedinde tezkeresi bulunmayan kimesneleriñ fakat def'leriyle iktifā oluna'.

${ }^{69}$ Ibid.: 'bu sūret her lakırdı söyleyen adam dimek olmayub re'āyā beyninde fesādı mü'eddī olacak sözleri söyleyen Yūnānī ve sāiir serseri makūlesi adam dimek olmaǵla buralarına güzelce dikkat oluna'. 
Citation : Aymes, Marc (2007) 'The Voice-Over of Administration: Reading Ottoman Archives at the Risk of III-literacy',

European Journal of Turkish Studies, Thematic Issue $N^{\circ} 6$, III-literate Knowledge, URL: http://www.ejts.org/document1333.html

To quote a passage, use paragraph (§).

[59] One can only wonder what kind of words were likely to arouse suspicion among the provincial administrators: as to this, Safvetī Paşa does not say a word. Most probably, it all boils down to a shared set of overtones - an implicit taxonomy allowing to recognize prima facie expressions of loyalty or sedition. Here one enters, as it were, the inner ear of Ottoman administration ${ }^{70}$.

\section{Rumour: Incoercible}

[60] The archives of the province yet harbour more voices than the administrators would have agreed to authorize: overwhelming their ears, an indistinct flow of contradictory rumours, illfounded suspicions and unwarranted accusations finds its way unto paper. It conveys a large, illliterate surplus of meaning, which ceaselessly put at risk the clear-cut taxonomies taken for granted by the Sublime Porte literati.

[61] Readers and hearers of innumerable petitions, the agents of the Ottoman sultan in the province are confronted with a vertigophony - a vertigo of voices that straddles the literacy/liliteracy dichotomy ${ }^{71}$. No sooner is a complaint submitted than another comes to contest its veracity, begging that 'neither attention nor consideration be granted' to it ${ }^{72}$. When 'Osmān 'İzzī Efendi, a former chief judge of the province of Cyprus, undertakes in 1845 to expose before the Sublime Porte the irregular proceedings of the local authorities, the archbishop of the island (soon joined by the members of the Lefkoşa council and other local religious leaders and merchants) disparages his claim as mere lies ${ }^{73}$.

${ }^{70}$ This inner ear could be a variant on what Jacques Rancière has called 'partage du sensible': 'On appellera partage du sensible la loi généralement implicite qui définit les formes de l'avoir-part en définissant d'abord les modes perceptifs dans lesquels ils s'inscrivent. [...] Cette répartition qui anticipe, de son évidence sensible, la répartition des parts et des parties présuppose elle-même un partage de ce qui est visible et de ce qui ne l'est pas, de ce qui s'entend et de ce qui ne s'entend pas.' (2004: 240; emphasis added).

${ }^{71}$ This notion of 'vertigophony' is intended as a free English translation of Alain Corbin's phrase 'le vertige des foisonnements' (1992). Corbin himself (103 n.1) recalls his indebtedness to Alphonse Dupront, 'Histoire de la psychologie collective et vie du temps', in L'Encyclopédie française t. XX (1959), chapter 3, p. 6.

${ }^{72}$ The original version reads: 'ihāle-i sem' ü i'tibār buyrulmamak.'

${ }^{73}$ BOA, A.DVN 7/19, report ('arīza) by the archbishop of Cyprus 'Yovānīkyos' (9 Zī'-ka'de 1260 [20 November 1844]): 'bu bābda mūmāileyhümānıñ serd ü beyān idecekleri hilāf-ı vāki' inhā ve ifādelerine ihāle-i sem' ü i'tibār buyrulmamak niyāzıyla [...] îrād olunan makālāt-ı kāzibeye bir vecihle ihāle-i sem' ü i'tibār buyrulmaması husūsı [...] niyāz-ı 'abīdānem idügi.' A round robin issued on the same day by the Lefkoşa council contains the 
Citation : Aymes, Marc (2007) 'The Voice-Over of Administration: Reading Ottoman Archives at the Risk of III-literacy',

European Journal of Turkish Studies, Thematic Issue $N^{\circ} 6$, III-literate Knowledge, URL: http://www.ejts.org/document1333.html

To quote a passage, use paragraph (§).

A few months later, when the Istanbul authorities issue an order summoning several of the affair's protagonists to the Ottoman capital, the case seems about to get settled:

[62] It has lately been observed and reported that the müfti of the island of Cyprus, together with the kocabaşı Ābeydo, the archbishop and other kocabaşıs, have indulged in certain improprieties with regard to the collection of the states revenues and of the canonical capitation, and in the distribution of annual taxes as well. Thus, following the sublime order issued on this matter, it has been required from the governor of the aforesaid island, the honourable Hācı Mesrür Agga, that the aforementioned persons be sent to the Porte of Felicity, and that the reported circumstances be elucidated and written down in all impartiality ${ }^{74}$.

[63] And yet, the conclusions of Hācı Mesrūr Ag̉a's investigations bring about a further suspension of judgment:

[64] It has been indeed deemed necessary, conforming to the sublime requisite of an imperial order, that the aforementioned persons be conducted and ushered to the Porte of Felicity, along with their register [of accounts]. Yet, with respect to the information minutely collected and heard, publicly and secretly, by the humble servant that I am since my insignificant arrival to the aforementioned island, it has been ascertained [...] that once arrived there [to Istanbul] these people will dare utter, during the investigation and interrogation that will take place, certain things regarding agents of the sublime sultanate who have come to the island since the beginning of the blessed reorganizations; that they will also ask 'Izzì Efendi, who presently is tax farmer of the aforesaid island, to be sent and summoned to the Porte of Felicity; and that currently they also prepare for calling to the Porte of Felicity many people, Muslims and Christians, who would testify in their favour. It clearly appears then that [...] this situation will bring about considerable irritation, by heaping much opprobrium on some servants illustrious for their fidelity, and weighing heavily on the honour-crowned heads of the high dignitaries of the sublime sultanate. [...] Consequently, and although this oversteps my prerogatives, it has been deemed more proper on my humble part that the aforesaid individuals

same exhortation (ibid.). See also BOA, I.MVL 1203, round robin (mahzar) dated 1'st Muharrem 1261 (10 January 1845): 'o makūle erbāb-ı mefsedetiñ kālen ve kalemen vukū'bulan hilāf-ı vāki' ifāde ü inhālarına ihāle-i sem' ü i'tibār buyrulmaması.'

${ }^{74}$ BOA, I.MVL 1317, round robin by the Supreme Council of Judicial Ordinances (or Meclis-i vālā) (7 Ramazān 1261 [9 September 1845]); this quoted passage is a digest summing up previous events: 'Kıbrıs cezīresi müftīsi ile kocabaşı Ābeydo ve başpiskopos ve sā'ir kocabaşılarıñ emvāl-i mīriyye ve cizye-i şer'iyye tahsīlātında ve tevzī'-i virgü husūsunda ba'zı uyg்unsuzlukları vukū'buldıġı mukaddemce rü'yet ve istihbār olundıġından merkūmlarıñ Dersa'ādet'e gönderilmesi ve keyfiyāt-ı merviyyeniñ garazsızca tahkīk ve tenmīk olunması husūsları müte'allik buyurılan irāde-i seniyye mūcebince cezīre-i merkūme kā'imakāmı 'izzetlü Hācı Mesrūr Aġa'ya sipāriş buyrulmuş olması....].' 
Citation : Aymes, Marc (2007) 'The Voice-Over of Administration: Reading Ottoman Archives at the Risk of III-literacy', European Journal of Turkish Studies, Thematic Issue $N^{\circ} 6$, III-literate Knowledge, URL: http://www.ejts.org/document1333.html

To quote a passage, use paragraph (§).

stay here; hence one would regularize and straighten their required accounts, and proceed with admonitions and reprimands, on this side ${ }^{75}$.

[65] The argument here stressed by the governor of Cyprus is that unauthorized words might get out of control if allowed to spread to Istanbul. It sounds more reasonable, he pleads, to fence in the rumours by circumscribing them in their provincial confines.

[66] Significantly enough, the argument seems to have convinced the Istanbul top brass: as far as one can know, the case in question eventually remains in the hands of local authorities ${ }^{76}$. One thus perceives the essential role that the Ottoman administration imparted to its provincial agents: incumbent on them is the task of 'forestalling' any kind of rumour, to 'cut it short' ${ }^{77}$. The aforequoted note is a case in point:

${ }^{75}$ Ibid., letter from the Cyprus governor Hācı Mesrūr Ag̉a (7 Receb 1261 [12 July 1845]): 'Dersa'ādet'e i'zāmları irāde-i seniyye iktizā-yı 'ālīsinden olan sābikü-z-zikr kesānıñ dahī defter-i mezbūre ile berāber sevk ü tesrïbleri egerçe lāzımeden bulunmuş ise de cezīre-i merkūmeye vürūd-ı çākerānemden-berü hafĩ ve celī vāki' olan tedkīkāt ve mesmū'āt-ı 'abīdāneme nazaren [...] bunları̃̃ ol-cānibe 'azīmetlerinde īcāb idecek tahkīk ü istintāk-ı vākı'ada bidāyet-i tanzīmāt-ı hayriyyeden berü cezīre-i merkūmeye vürūd iden me'mūrīn-i saltanat-ı seniyye hakklarında ba'zı mertebe cevāblar īrād iderek muhākemeye cü'retle el-hāletü hazihi cezīre[-i] mezbūre gerek mültezimi bulunan 'İzzī Efendi bendelerini dahī Dersa'ādet'e celb ü da'vet eyleyecekleri ve bu sırada tarafına hüsn-i şehādet zımnında islām ve re'āyādan haylī kesānıñ dahī Dersa'ādet'e 'azīmete müteheyyi idükleri lede-t-taharrī rü'yet-i hālden tahakkük itmiş oldıg̉ına ve bu keyfiyet bir takım bendegān-ı sadākatnişān hakklarında bir nev'-i hacāleti mūcib ve tasdī'-i ser-i şeref-efser-i vükelā-yı saltanat-ı seniyyeyi müstevcib dag̉daġa-ı 'azīm olacag̉ı[...] vâzıheden bulundıg̉ına binā'en [...] zikr olunan kesānıñ burada tevkīfleriyle muhāsebe-i lāzımeniñ ta'dīl ü istirdā[d]ı ve tenbīhāt ü tevbīhātıñ bu cānibde icrāsı husūsı min ġayri haddin nezd-i 'abīdānemde tasvīb kılınmış.'

${ }^{76}$ Ibid., memorandum ('arz tezkiresi) (n.d., date overleaf: 2 Şevvāl 1261 [4 October 1845]): in a way that closely paraphrases the recommendation of the governor of Cyprus, the grand vizier concludes that 'the aforesaid accounts should be examined there, and reports concerning the situation be sent to the Porte of Felicity' (muhāsebe-i merkūmeniñ ol-tarafda bi-I-rü'ye keyfiyetiniñ Dersa'ādet'e bildirilmesi); which is approved by the adjoining sultanic order.

${ }^{77}$ As expressed in Ottoman by the phrase 'öñü kesmek', which frequently appears when it comes to unauthorized utterances in period documents. See for example BOA, I.MVL 139, round robin (mazbata) of the Cyprus council (n.d. [ 1840]): 'cevāb tahrīiryle sızıldınıñ [sic] öñüni kesmiş' ('with his answer he forestalled murmurs'). Compare Reinkowski 2005: 301. 
Citation : Aymes, Marc (2007) 'The Voice-Over of Administration: Reading Ottoman Archives at the Risk of III-literacy', European Journal of Turkish Studies, Thematic Issue $N^{\circ} 6$, III-literate Knowledge, URL: http://www.ejts.org/document1333.html

To quote a passage, use paragraph (§).

[67] Supposing the things that have been heard adjoin the truth, they [the provincial governors] will be held accountable for having not understood and signalled it in due time ${ }^{78}$.

[68] Noticeable here is the phrase 'in due time' - that is, before the rumour surges and gets audible as far as Istanbul, out of its proper proportions. In other words, provincial administrators are relentlessly exhorted to contain the rumour, so that nobody can spread the word ${ }^{79}$. The tone and the rhetoric may vary, according to circumstances. Dilatory:

[69] There seems to be a possibility that from now onwards, through wise proceedings, the question could be left pending and in abeyance, without this causing any kind of murmur or complaint ${ }^{80}$.

[70] Conciliatory:

Because of the circumstances and of the current affairs, the surest and fittest way is to leave them [foreigners who acquire real estate properties] in peace this year; as has formerly been the case one should take care to satisfy and silence them with wise measures, so that the matter be settled promptly and without murmurs ${ }^{81}$.

[71] Martial:

Some trouble-makers are eager to cash in on the harmful effects of the revolutions in Europe, and they will mix with the inhabitants of the White Sea islands; it is hence necessary to scrutinize with attention the situation of these places, and, if

${ }^{78}$ BOA, A.MKT 107/33, draft of a memorandum sent to several provincial governors (n.d., two distinct dates overleaf: 17 Muharrem 1264 [25 December 1847] and 2 Safer 1264 [9 January 1848]): 'işidilen şeyler mukārini sıhhat oldığı hālde vaktiyle añlayub 'arz ü inhā olunmadıġından tolāyı me'sūliyet üzerlerinde kalacaġı.'

${ }^{79}$ Frequently used phrases, such as 'şudur diyecek mahal kalmamış' or 'şudur diyecek yer kalmamak üzere', testify to this preoccupation. See BOA, I.MVL 352, round robin (mazbata) by 'Ömer Paşa and the main authorities of Cyprus (27 Safer 1257 [20 April 1841]); BOA, A.MKT 104/3, annotated instructions (ta'līmāt) to 'Abdülvahhāb Efendi (n.d. [ 1846-47]). Compare Reinkowski 2005: 301.

${ }^{80}$ BOA, A.MKT 42/90, report ('arīza) by the governor of Cyprus Hasan Paşa (11 Rebī'ü'l-āhir 1262 [8 April 1846]): 'bir gūnā sızıldı ve makālāta sebeb virmeyecek derecelerde arasınıñ uzadılub terk ü tevkîf olunması dahī bundan soñra sūret-i hakīmānede ba'zı esbāba teşebbüs ile mümkinātdan görünmüş' (emphasis added).

${ }^{81}$ BOA, I.HR 116, memorandum ('arz tezkiresi) (n.d. [ February 1840]) paraphrasing a letter from the governor of d'Izmīr, concerning foreigners holding real estate and their fiscal status: 'hasbeü-I-vakt ve-I-maslaha[t] bu senelik pek-de üzerlerine varılmayarak sābıkı vechile hüsn-i sūretle sızıldısızca [sic] tedābir-i hakīmāne ile irzā ü iskātlarılyla tesviyesine i'tinā olunması eslem ve enseb olacaġı' (emphasis added). Many thanks to Alp Yücel Kaya for having signalled this document to me. 
Citation : Aymes, Marc (2007) 'The Voice-Over of Administration: Reading Ottoman Archives at the Risk of III-literacy',

European Journal of Turkish Studies, Thematic Issue $N^{\circ} 6$, III-literate Knowledge, URL: http://www.ejts.org/document1333.html

To quote a passage, use paragraph (§).

any trace of a move comes out, to repress it at once without wasting time on words ${ }^{82}$.

[72] Versatile as it may be, this rhetoric of containment always points to the same soundbite: words are to be spared.

[73] Again, yet, one has reasons to believe that provincial chatter more often than not overruns the administrators' discernment and laconicism. For it confronts them with an unremitting profusion, disregarding the discretion of authorized and contained speech. Profusion is the word that first comes to mind when one opens the hefty file containing all the petitions, letters and round robins that piled up at the Sublime Porte during the autumn 1840, with regard (among others) to the two Lefkoşa kocabaşı Ācī Kirgekī and Ābeydo. An affair even more inextricable than the case put forth by 'İzzī Efendi in 1845, it offers a crucial example of how a set of rumours could unbalance the Ottoman politics of provincial containment ${ }^{83}$. As a matter of fact, those petitioning against the kocabaş/s' pretended malpractices have secured the sponsorship of the Istanbul Greek patriarch before the Sublime Porte ${ }^{84}$. But above all, several Cypriots have taken the initiative to come to the capital and bring the case to the ears of Istanbul high dignitaries. In contravention of the obligation to hold a 'passage permit', and without any consideration for the local governor's prerogatives, a small group of islanders have 'fled' to Istanbul; another party comes to the Porte hot on their heels, led by loannikios, a Cypriot churchman long exiled in France - and soon to become archbishop himself (Dionyssiou 1995: 36). 'The two parties being present at the Threshold where imperial majesty rests, both of them have been summoned to the Supreme Council [of Judicial Ordinances] to be questioned and interrogated again and again' ${ }^{85}$. Some charge the incriminated kocabaş/s with various frauds, others plead

${ }^{82}$ BOA, A.MKT 119/15, draft of an order to the Commander-in-chief of the Army (Ser'asker) (n.d., date overleaf: 3 Cemāzīu'l-evvel 1264 [7 April 1848]): 'Āvrûpā'nıñ intilāāāını̃̃ āsār-ı muzırresinden istifāde itmek isteyen ba'zı şūiş̧-kārlarıñ Akdeñiz'de bulunan atalar ahālisi ile intilātları ziyāde olacag̉ından oralarıñ hāllerine rekz-i nazar dikkat olunması ve bir gūne eser-i hareket zuhūr ider ise lakırdı uzamaksızın derhāl oldığı yerde basdırıması lāzımeden olacaǵı [...]' (emphasis added).

${ }^{83}$ On this affair elements are to be found in Dionyssiou 1995: 32-36. A condensed - and oversymplifying paraphrase of the BOA file in hand is offered by Uzun 2002: 18-22.

${ }^{84}$ BOA, I.MVL 139, letter from the 'İstanbul Rūm patrïgi' Antīmos (n.d. [ spring-summer 1840]): 'bu çākerlerine terkīm ü tesyīr eyledikleri Rūmī el-imlā üç kıt'a 'arz ü mahzarları.'

${ }^{85}$ BOA, I.MVL 139, round robin (mazbata) from the Meclis-i vālā (n.d. [ autumn 1840]): 'tarafeyn Āsitāne-i şevket-āşiyāne'de bulunmuş oldıg̉ından bi-d-defa'āt Meclis-i vālā'ya celb ile isticvāb ü istintāk olundukda.' 
Citation : Aymes, Marc (2007) 'The Voice-Over of Administration: Reading Ottoman Archives at the Risk of III-literacy',

European Journal of Turkish Studies, Thematic Issue $N^{\circ} 6$, III-literate Knowledge, URL: http://www.ejts.org/document1333.html

To quote a passage, use paragraph (§).

in their favour - while some also seize the opportunity to push themselves forward... The Council also hears the testimony of a 'former nakīb [registrar of the descendants of Muhammed] in Cyprus', whose name sounds familiar since the man in question is 'Izzī Efendi himself, only recently arrived to Istanbul. And four judges formerly in office in the island, who happen to stay in the capital for others affairs at the moment, are solicited on the matter as well: 'as they came several times to the Supreme Council to explain their situation, on that occasion they were also questioned concerning their knowledge of the condition of the aforesaid island ${ }^{86}$. One audience after another, the Porte high dignitaries thus repeatedly listen to the multiple versions of a case that divides into several ramifications, soon overwhelmed by a rumour that has become incoercible.

[74] Lest exasperation would gain momentum, soon comes the time for decision-making. First comes the main recommendation issued by the Supreme Council of Judicial Ordinances:

[75] Since so much tittle-tattle has occurred, and as the tranquility of the inhabitants is, under the justice-lavishing aegis of His Imperial Majesty, a requirement that must be satisfactorily met, it cannot be deemed proper that the aforementioned lord ['Osmān Beg, governor of Cyprus at that time] stay there from now onwards. Consequently he should be dismissed, and to his post one should appoint a fit person among the servants of the sublime sultanate, somebody who certainly understands the principles of the blessed reorganizations, knows about imperial affairs and is familiar with the rules and administration currently in force ${ }^{87}$.

[76] Strikingly enough, 'tittle-tattle' ranks first among the motives for this decision. To be sure, the latter is prompted by the conviction that such rumours are indeed grounded: the Council report stresses that 'the charges [against the kocabaş/s] actually and mainly stem from the unsettling and improper initiatives' taken by the governor to blame ${ }^{88}$. All in all, yet, the mere risk that a rumour could

${ }^{86}$ Ibid: 'mukxaddemce Dersa'ādet'e gelmiş olan Kıbrıs nakībi sābik 'Osmān 'İzzī Efendi ile muhassıl-ı esbāk-ı müteveffa 'Osmān Hayrī Paşa zamanında cezīre-i merkūmeniñ ba'zı kazāları niyābetinde bulunub niyābet-i mezkūreye me'mūriyetlerinde vukū'bulan masāriflarından tolayı istid'ā-yı 'ināyet iderek 'arzuhālleri bu def'a Meclis-i vālā'ya i'tā buyrulmuş olan dört nefer nā'ib efendiler birkaç def'a Meclis-i vālā'ya gelüb ifāde-i hālleri sırasında cezīre-i merkūme ahvāline dāiir olan ma'lūmātlarından dahī istintāk olundukda.'

${ }^{87}$ Ibid., mazbata from the Meclis-i vālā (n.d. [ early September 1840]): 'mādemki bu kadar iştikā ve kīl ü kāl vukû'bulmuş idügüne ve sāye-i ma'delet-vāye-i hazret-i şāhānede āsāyiş-i ahāli kaziye-i merziyyesi lāzimeden bulundıg̉ına binā'en bu hālde mīr-i mûmāileyhiñ ba'dezīn orada bakāsı uyamayacaǵından 'azliyle yerine usûl-i tanzīmāt-ı hayriyye'ye vākıf ve mesālih-i seniyyeyi 'ārif ve usûl ü idāre-i hāliyyeye vukûfli der-aşīkār bendegānI saltanat-ı seniyyeden münāsib bir zāt muhassıl ta'yīn [buyrulması].'

${ }^{88}$ Ibid.: 'asl-i başlıca iştikāları muhassıl-ı mūmāileyhiñ yolsuz ve uyg̉unsuz hareketlerinden oldığı añlaşılmış.' 
Citation : Aymes, Marc (2007) 'The Voice-Over of Administration: Reading Ottoman Archives at the Risk of III-literacy',

European Journal of Turkish Studies, Thematic Issue $N^{\circ} 6$, III-literate Knowledge, URL: http://www.ejts.org/document1333.html

To quote a passage, use paragraph (§).

spin out of control appears to stand as an all-important reason, in the name of 'the tranquility of the inhabitants.'

[77] This primacy is conveyed in an even more manifest manner in the memorandum transmitted to the Sultan's cabinet by the grand vizier. It contains a supplementary recommendation, which the Council report did not feature, with regard to the archbishop of Cyprus:

[78] [...] and although the behaviour of the aforesaid archbishop has shown no impropriety so far, some tittle-tattle has come out on his account; consequently, he too should be dismissed and replaced, and to his office another fit person should be chosen and appointed ${ }^{89}$.

[79] One certainly cannot ignore that the man who is then elected to succeed him, the aforementioned loannikios, most probably profited from staying and networking in Istanbul in order to secure the post ${ }^{90}$. Yet it remains meaningful that, even in the most eminent and confidential Ottoman correspondence, the argument of gossip still suffices for justifying the archbishop's dismissal. As soon as it risks becoming uncontainable, the tumult of rumour - be it grounded or not, this is not the point - precipitates the authorities into decision.

\section{Rogue Words}

[80] Still this is nothing: for, in all that precedes, the hubbub remained confined to official authorities, whether in Cyprus or in Istanbul. This is precisely what the governor of the island stresses, in a round robin signed by the local council regarding the case of Ācī Kirgekī and Ābeydo:

[81] Since your humble servant came here, Muslims and non-Muslims alike have seemed satisfied with these kocabaşıs, and only favorable opinions have been

${ }^{89}$ Ibid., memorandum ('arz tezkiresi) (n.d. [ mid-September 1840]): 've piskopos-ı merkūmuñ şimdiki hālde uyǵunsuzlıg̉ı pekde tebeyyün itmemiş ise de hakkında ba'zı mertebe kīl ü kāl vukū'bulmuş idügünden anıñ dahī 'azl ü tebdīliyle yerine āhar münāsibiniñ intihāb ü ta'yīn itdirilmesi.'

${ }^{90}$ Dionyssiou (1995: 34) explains that during the 1830s, 'loannikios [...] was living in Paris, where he was acquainted with Reşit Paşa during his ambassadorship in Paris and London (1834-1837) and in Paris (18361837). He was also acquainted with Ahmet Fethi Paşa, son-in-law of the Sultan Mahmud II. [...] Both of them helped him later to ascend the Archbishopric throne of Cyprus.' Dionyssiou more specifically refers to Georgiou 1975: 125-126; he also produces (1995: 242-248) two documents which attest to the future archbishop's networks among Ottoman high officialdom. 
Citation : Aymes, Marc (2007) 'The Voice-Over of Administration: Reading Ottoman Archives at the Risk of III-literacy',

European Journal of Turkish Studies, Thematic Issue $N^{\circ} 6$, III-literate Knowledge, URL: http://www.ejts.org/document1333.html

To quote a passage, use paragraph (§).

heard at the marketplace or the bazaar; as a matter of fact, murmurs come from the council, which arguably implies that the case is a personal one ${ }^{91}$.

[82] The poll procedures adopted here imply that public places such as the marketplace and the bazaar sometimes become a symbolic arena where provincial rumours put the Ottoman authorities to the test. The military commander sent to Cyprus from Beyrouth in the early 1840s thus orders his troops 'to station a patrol in the marketplace of the area where they are positioned, to seize and apprehend those who quarrel and brawl, and to bring them before the official entrusted with the maintenance of public order' ${ }^{92}$. Then he relates a telling episode:

[83] One day the non-Muslim party in Lefkoşa closed their shops and went to the bishop, declaring 'We have been told that the Muslims will kill us all.' The aforesaid bishop reported the situation to the colonel entrusted with the maintenance of public order in the aforesaid place, your humble servant Mustafa Beg, and truly the aforementioned lord your servant then behaved clear-sightedly: accompanied by rank and file troops from his following, he went to the market, and had public criers proclaiming that under His Sovereign Majesty's might-lavishing aegis nobody would harm anybody; then he ordered that the market be reopened ${ }^{93}$.

[84] The marketplace hence appears to be a privileged setting for the Ottoman authorities to test their procedures of rumour containment: there a tumult could arise at any time, there it should be repressed at once. And interestingly enough, recourse is had to the unwritten words of 'public criers' to this end. Marketplaces then, insofar as they symbolize 'the manifestation, first verbal only, of a disposition to nurture agitation, which is likely to materialize in violent acts on the occasion, for example, of a public meeting' (Reinkowski 2005: 247) ${ }^{94}$, appear as a metonymic site of provincial ill-literacy.

${ }^{91}$ BOA, I.MVL 139, mazbata from the Lefkoşa council (n.d. [ 1840]): 'çākerleri bu tarafa gelidenberü şu kocabaşılardan gerek islām ve gerek re'āyāyı hoşnut görmüş ve çarşu ve bāzārdan dahī hüsn-i hālleri işidilmiş ve bu sızıldı vākı'ā meclisden haber virildigi üzere teferrüd da'vāsından 'ibāret idügü fehm olunmuş.'

${ }^{92}$ BOA, I.MVL 352, report by the commander (mīr-livā) 'Ömer Paşa (n.d. [ 1841-42]): 'bulundukları mahallerde çarşuya birer karag̉ol vaz' ıyla ġavg̉a ü nizā' idenleri ahz ü girift iderek zabtiye me'mūrına getürmeleri.'

${ }^{93}$ Ibid.: 'bir gün dahī Lefkoşa'da re'āyā tā'ifesi dükkānlarını kapayarak piskoposa gelüb 'müslümānlar bizi kıracaklar imiş' deyü ifāde itmeleriyle piskopos-ı mersūm keyfiyeti mahal-i mezkūruñ zabtiye me'mūrı olan mīrālāy Mustafa Beg kullarına haber virmiş ve mīr-i mūmāileyh kulları dahī tog̉rısı bu sırada ziyāde dirāyet-kārāne hareket iderek derhāl ma'iyetinde olan zabtiye neferātını bi---istishāb çarşuya çıkub münādiler nidāsıyla sāye-i kudret-vāye-i cenāb-ı mülūkānede kimesneniñ kimseye bir şey idemeyecegini i'lān ile tekrār çarşuyı açdırmış'.

${ }^{94}$ With regard to the Ottoman notion of 'kīl ü kâl': 'eine vorerst nur verbal geäußerte Disposition zum Aufruhr, die sich sehr rasch z.B. in einer Zusammenrottung (cumhūr/cem'iyyet) materialisieren kann.' 
Citation : Aymes, Marc (2007) 'The Voice-Over of Administration: Reading Ottoman Archives at the Risk of III-literacy',

European Journal of Turkish Studies, Thematic Issue $N^{\circ} 6$, III-literate Knowledge, URL: http://www.ejts.org/document1333.html

To quote a passage, use paragraph (§).

And this metonymy itself, as a language device, is a means to subdue truly untenable utterances words nobody knows whenever, wherever, whomever they could pop up. Rogue words.

[85] The universe of Ottoman provincial archives, patterned as it is by the necessity to check public voicings, still lets these provincial rumours surface here and there. You can hear these rogue words, mired in sarcasm and vilification. Those words are not real words, the masters of the archival pen posit: they rather resemble something like a whine, a squawk, a squeak, or a gurgle perhaps; here a barely audible whisper, there a vociferous outcry, fiery beyond measure. Do you insist that more proper introductions should be done? Very well then, but you will have been warned ${ }^{95}$.

[86] At first, these utterances resemble any other, sound like ordinary talk $\left(g u ̈ f t ~ u ̈ ~ g \bar{u}^{-96}\right)$. Yet they can suddenly grow bitter and noxious ${ }^{97}$, exaggerated (mübālaġa $\left.{ }^{98}\right)$. Once divulged (şāyía ${ }^{99}$ ), their noise (gürültü̈ ${ }^{100}$ ) quickly soars: it soon becomes a deafening clamor ( $\left.\dot{g} u|\dot{g} u|^{101}\right)$ of tittle-tattle and

${ }^{95}$ The following survey draws on a sample of multiple documents (quoted previously or later on in the present article): BOA, I.MVL 139, round robins from the Māgosa (1er Rebī'ü'l-āhir 1256 [2 June 1840]) and Lefke (5 Rebī'ül-āhir 1256 [6 June 1840]) councils; ibid., report by the kocabaşıs 'Ācī Kirgekī' and 'Ābeydo' (n.d. [ 1840]); I.MVL 352, 'ariza signed by the governor of Cyprus 'Mehmed Tal'at' and by 'Es-seyyid Mustafa', colonel appointed to the maintenance of public order in the island (7 Safer 1257 [31 March 1841]); ibid., mazbata by 'Ömer Paşa and the main authorities of the island (27 Safer 1257 [20 April 1841]); ibid., report by the commander (mïr-livā) 'Ömer Paşa (n.d. [ 1841-42]); A.MKT 104/3, annotated draft of the instructions to 'Abdülvahhāb Efendi (n.d. [ 1846-47]); I.HR 3924, draft of the 'confidential instructions' (ta'līm-nāme-i mahremāne) to the Imperial Council translator, destined for Stratford Canning (n.d. [ October 1851]); I.DH 17270, report by the governor of Cyprus Mehmed Şerîf Paşa (16 Şevvāl 1269 [23 July 1853]); I.DH 17572, mazbata signed by Mehmed Rā'if, financial registrar (defterdār) and substitude (kā'im-makām) of the governor-general (vālì) of the Islands, and others (19 Şevvāl 1269 [26 July 1853]). — See also the occurrences registered by Reinkowski 2005: 301.

${ }^{96}$ Redhouse 1890: 1556 ('güft: 1. A word spoken. 2. A speaking' et 'güft ü gū: 1. Talk, conversation, chat. $\left.[\ldots]^{\prime}\right)$.

${ }^{97}$ Ibid.: 'güft ü gū: [...] 2. Discussion; dispute. 3. Criticism, scandal'.

${ }^{98}$ Ibid: 1668 ('mübālaġa: 1. A using one's utmost strength; utmost exertion. 2. An exaggerating; exaggeration').

${ }^{99}$ Ibid.: 1112 ('şā'i',vulg. şāyi': Divulged, spread abroad, commonly known'; et 'şây'ia: A rumor, news in general circulation').

${ }^{100}$ Ibid.: 1587 ('gürüldü, vulg. gürültü: 1. A loud noise of any kind. 2. An uproar; tumult; disturbance').

101 Ibid.: 1349 ('ǵulgul: 1. Repeated loud notes or warblings of birds. 2. The clamor of a multitude. 3. The gurgling of a bottle. 4. The echoes of a vault, etc.'). 
Citation : Aymes, Marc (2007) 'The Voice-Over of Administration: Reading Ottoman Archives at the Risk of III-literacy',

European Journal of Turkish Studies, Thematic Issue $N^{\circ} 6$, III-literate Knowledge, URL: http://www.ejts.org/document1333.html

To quote a passage, use paragraph (§).

gossip ( $k i ̄ l u ̈ ~ k a ̄ l^{102}$ ). Add to this a few insinuated calumnies (erāciff ${ }^{103}$ ), and the lamentations (sızıld ${ }^{104}$ ) of this cantankerous multitude $\left(\dot{g} a v \dot{g} a^{105}\right)$ degenerates into sheer riot ${ }^{106}$.

[87] Such is the vast lexical repertoire of ignominy-clad words deployed by Ottoman administrators to stigmatize provincial ill-literacy. So much does this cacophony jar their decorous language, that they cannot echo it without a murmur of reprobation or a sign of repentance. Mustafa Beg, commander in charge of maintaining public order in Cyprus, adopts this very contrite stance when relating the 'imaginations' (evhām) nurtured among the Christians of Lefkoşa on Monday, 5 Safer 1257 (29 March 1841):

[88] Those are not things that should be said, but as they could be fetched in a different way by somebody else to the soil trodden upon by His comfort-lavishing Majesty, so did the temerity to relate them ensue. All this caused no glitch in the affairs of the Sublime State, and we remain up and running as ever. My humble plea is that no consideration be granted by His Excellency to any other information and informant ${ }^{107}$.

[89] I have to say it, though I would prefer not to: there is indeed nothing that should be said. The only motive for repeating these unconveyable 'things' is the risk that anybody else might report them otherwise - which, Mustafa Beg suggests, would boost further ungrounded rumours. Hence the necessity to write down on paper the trace of a 'glitch' that should go unnoticed right away.

[90] This refusal to acknowledge the audibility of non-authorized words not only matches the cognitive taxonomies that have been pinpointed earlier among the Ottoman administrators: it also stems from the categories of what could be termed a practical sociology. Some people utter words which deserve to be listened to; as to all the others, they have no word. By closely examining the

102 Ibid.: 1419 ('kīl ü kāl: Tittle-tattle').

${ }^{103}$ Ibid.: 57 ('erācīf: Idle, false rumors, calumnies, and the like, disseminated maliciously').

${ }^{104}$ Ibid.: 1199 ('sızıldI: 1. Lamentation and complaint. [...]').

${ }^{105}$ Ibid.: 1354 ('ǵavġa: 1. A noisy multitude. 2. An outcry of mingled voices, a tumult. 3. (vulg. kavġa) A contest, quarrel, brawl. 4. A fight, battle').

${ }^{106}$ Ibid:: 1199 ('sızıldl: [...] 2. Public murmurs, and complaint; any public expression of dissatisfaction; a riot').

${ }^{107}$ BOA, I.MVL 352, petition ('arzuhāl) bearing no signature (the author most probably being Mustafa Beg) (7 Safer 1257 [31 March 1841]): 'bu ifāde idecek bir şey degil ise de taraf-ı āhardan hāk-ı pā-yı hazret-i veliyyin-nu'maya başka vechile ifāde olunur mütāla'asıyla ifādeye cesāret olundı ve bundan tolayı mesālih-i Devlet'aliyye'ye bir sekte gelmeyerek kemā fî-s-sābık işimizde gücümüzdeyiz başka bir haber ve āhara [sic] i'tibār buyurmamaları niyāz-ı bendegānem idügi.' 
Citation : Aymes, Marc (2007) 'The Voice-Over of Administration: Reading Ottoman Archives at the Risk of III-literacy',

European Journal of Turkish Studies, Thematic Issue $N^{\circ} 6$, III-literate Knowledge, URL: http://www.ejts.org/document1333.html

To quote a passage, use paragraph (§).

whys and wherefores of such a sociological divide, one can better understand the extent to which late Ottoman provincial administration rests on a monopolization of legitimate literacy.

[91] The correspondence of Ottoman officials in Cyprus contains frequent references to local people who are called - if translated literally - the 'word holders' (söz sāhibleri). This very term, 'söz', testifies to the matters of authority that are at stake here: it refers to the pledge of a promise, to the determination of an order, to the resolution of a case pleaded - and finally, in short, to sheer influence ${ }^{108}$. This word is endowed with gravity then: a pondered, well-chosen word, which has a bearing on future events. More than just a word, 'söz' sounds as if it was a title, a distinction that cannot be awarded but thoughtfully. To be acknowledged as a 'word holder', one must be as good as one's word. In short, one has to be a 'word keeper' ${ }^{109}$.

[92] How to understand the entitlement which is here at play? One may suggest relating it to a certain Ottoman concept of notability. 'Word keepers' are indeed notable, first and foremost due to their eloquence ${ }^{110}$. They are people whose speech complies with the patterns of a literate turn of phrase, of the kind that can easily be edited on paper. It comes as no surprise then that in some documents the phrase 'söz başı' is substituted for 'söz sāhibi': significantly enough, it literally refers to the title of a book chapter or to a paragraph 'head' ${ }^{111}$... But along with this silver-tongued oratory, other criteria shape the notability in question: in the order of precedence established through Ottoman terms of address, 'word keepers' quite often rank in the same position as Christian kocabaşı $\mathrm{s}^{112}$;

${ }^{108}$ Redhouse 1890: 1090 ('söz: 1. Any word or words spoken or written. 2. A promise, agreement, compact. 3. A command. 4. An objection. 5. An assertion, an opinion. 6. An accusation. 7. An argument; a plea. 8. Conversation. 9. A remark, observation. 10. Influence'). One should also note that, in the Ottoman administrators' parlance, the main quality of docile subjects is the ability to 'get the word' (söz añlamak) (ibid.: 'To understand and be persuaded or heed').

${ }^{109}$ Which is the translation that I suggest adopting henceforth for 'söz sāhibleri.'

${ }^{110}$ Redhouse 1890: 1091 ('söz sāhibi: An eloquent man').

111 Ibid.: 1091 ('a heading of a chapter, section, paragraph, etc.'). See BOA, I.MVL 7270, annex document (zeyl) written by Sırrı Efendi (19 Cemāziü'l-evvel 1267 [22 March 1851]): 'mütemevvil ve söz başı olanlar.'

${ }^{112}$ BOA, A.DVNS.MHM.d 248, $n^{\circ}$ 426, order to Mehmed Es'ad Medhī Beg and to the authorities of Cyprus (evāill Rebī'ü'l-āhir 1247 [9-18 September 1831]): 'gerek ehl-i islāmdan söz sāhibi ve gerek re'āyādan kocabaşı.' It does not necessarily imply that all 'word keepers' be Muslims: a document from 1821 mentions certain 'söz sāhibi gāvurlar' (kept at Sofia Cyril and Methodius National Library, under the reference NBKM, Or. Otd., F. 275A, a.e. 243; fac-simile in Theocharidis 1980: 156. 
Citation : Aymes, Marc (2007) 'The Voice-Over of Administration: Reading Ottoman Archives at the Risk of III-literacy',

European Journal of Turkish Studies, Thematic Issue $N^{\circ} 6$, III-literate Knowledge, URL: http://www.ejts.org/document1333.html

To quote a passage, use paragraph (§).

and in the provincials' parlance also, they count among 'those among us who stand in the front rank' (ilerüye gelenlerimiz) ${ }^{113}$. In Albert Hourani's words, such phrases point to 'those who can play a certain political role as intermediaries between government and people, ${ }^{114}$. In short, the prerequisites for being a 'notable' closely knit together the mastery of a certain oral literacy and the ability to take place within a sociopolitical configuration straddling local and imperial power networks.

[93] One should stress though that this group includes many more people than the few most prominent figures of local government. As far as non-Muslims as concerned, a round robin from the Tuzla district council, dated May 31, 1840, suggests that the 'word keeper' title spans a wider spectrum than that of 'notable'. It spells out a neat hierarchical ladder: on the one hand there are the officially recognized dignitaries who take part in provincial administration - 'the bishop and the kocabaşı who are the community leaders', also called 'the notables of our community' (milletimiz hātırlüleri) ${ }^{115}$, - and, on the other hand, a larger and humbler body of 'word keepers.' The core of this document is worth being quoted in full:

[94] We humbly gained knowledge of the tenor of the sublime order presently granted with favour, which stipulates that the question 'Is it fortunate or not for the humble ones that the kocabaşıs Hācī Kïrgĩ and 'Abeydo become members of the council?' should be investigated among the small and the big ones, and reported in truth by the council to the soil trodden upon by His fortunate Excellency. When, in compliance with the order of His fortunate Excellency, this was asked in council session to the bishop and the kocabaşı who are the community leaders, they answered: 'If the question is to be asked to those among us who stand in the front rank, a quarter of our word keepers will not testify in their favour, and most of them will tell that they are harmful. Indeed, while questioned about these two's condition by the notables of our community, who always stand by our side, they show their discontent. Now if we were to declare 'It's fine' regarding them, it would

${ }^{113}$ I.MVL 139, mazbata de l'assemblée du district de Tuzla (29 Rebīiü'l-evvel 1256 [31 mai 1840]): 'ilerüye gelenlerimizden su'āl olunsa söz sāhiblerimiziñ dörtde biri iyiliklerine şehādet itmeyüb' (see the complete quotation hereafter).

${ }^{114}$ Hourani 1968: 48. See also Makdisi 2000: 34 ('The notables were often referred to in Ottoman as söz sahibleri, those who have a say and the 'masters of words' in an overwhelmingly illiterate society') and 45 ('a notable was the face and voice of respectable society (awjuh al-bilad in Arabic; söz sahibleri in Ottoman).').

${ }^{115}$ If indeed one were to choose an Ottoman term conveying the various connotations of the word 'notable', this 'hātırlü' would seem quite indicated. See Redhouse 1890: 821-822 ('hātır. 1. A thought, an idea, a suggestion. 2. The mind. 3. The memory. 4. The heart as a seat of thoughts and impressions. 5. A recollection of a person or thing, accompanied with love, respect, or veneration. 6. One's feelings, frame of mind, health. 7. One's influence, consideration, weight'). 
Citation : Aymes, Marc (2007) 'The Voice-Over of Administration: Reading Ottoman Archives at the Risk of III-literacy',

European Journal of Turkish Studies, Thematic Issue $\mathrm{N}^{\circ} 6$, III-literate Knowledge, URL: http://www.ejts.org/document1333.html

To quote a passage, use paragraph (§).

necessarily imply that we do not show respect for the inhabitants' views, and our position would be amiss. But if our archbishop issues an order commanding us to testify in their favour, then we will certify their good condition as well.' $[. . .]^{116}$

[95] One could not have more clearly manifested the many contestations and compromises which in the end give way to words duly authorized and sanctioned. And also, it appears that the 'masters of words'117 do not always stick willingly to their Master's voice. Perhaps because of their lesser involvement (as compared to bishops or kocabaşıs) in official local administration, they do not need to deploy the 'cautious and even ambiguous modes of action' that characterize the Houranian 'notables' (Hourani 1968: 46). No need then to restrict their repertoire to the tight coat of an 'interaction between the Ottoman public order and the ecclesiastical order' ${ }^{118}$. Rather than posing in the stiff decorum of provincial administrative networks, one should imagine them arguing in a buzzing village place, or on the threshold of a countryside chapel.

[96] Now there is a sentence one needs to read twice: 'if we were to declare 'It's fine' regarding them, it would necessarily imply that we do not show respect for the inhabitants' views' ${ }^{119}$. According to what Tuzla's bishop and kocabaşı declare here, 'word keepers' would appear to be spokesmen of a sort. Does it imply that their titles of notability also derive from some kind of representative legitimacy, whose advent would have been brought about (or so certain historians say) by the 'reorganization' of provincial councils at that time ${ }^{120}$ ? Relevant as it may sound, this hypothesis

${ }^{116}$ BOA, I.MVL 139, mazbata from the Tuzla district council (29 Rebī'ü'l-evvel 1256 [31 May 1840]): 'Kocabaşı Hācī [sic] Kĩrgī ve 'Abeydo [sic] kullarınıñ meclise idhālleri fukarā hakkında hayır mıdır degil-midir Tuzla kazāsı sıg̉ār ü kibārından tahkīk ve 'ala vechi-s-sıhhat keyfiyetiñ hāk-ı pā-yı devletlerine meclisce 'arz ü inhā olunması beyānında bu def'a insān buyurılan fermān-nāme-i 'ālīleri müfādından ma'lūm-ı çākerānemiz olmuş fermūde-i devletleri üzere meclis olarak rü'us-ı milletleri bulunan piskopos ve kocabaşıdan isti'lām olundukda mersūmānıñ keyfiyetleri ilerüye gelenlerimizden su'āl olunsa söz sāhiblerimiziñ dörtde biri iyiliklerine şehādet itmeyüb ekserisi muzırr olduklarını haber virecekler hālbuki her-bār yanlarımıza gelüb giden milletimiz hātıllülerinden bunlareyn hālleri istintāk olundukda mersūmāndan 'adem-i hoşnūdına izhār itmeleriyle şimdi bizler bunlar içün iyüdir demiş olsak ahāliniñ re'ylerine mütāba'at itmeyüb hilāfında olmamı īcāb idecek ancak baş piskoposumuz tarafından tarafımıza emr zuhūrıyla mersūmān hakkında hüsn-i şehādet itmemizi re'y ider ise ol-zamān bizler-de hüsn-i hālleriçün şehādet ideriz deyü cevāb itmeleri [...].'

${ }^{117}$ To quoted Makdisi's translation (2000: 34): 'söz sahibleri, those who have a say and the 'masters of words'. ${ }^{118}$ Anagnostopoulou 2002: 283 ('interaction entre l'ordre public ottoman et l'ordre ecclésiastique').

${ }^{119}$ BOA, I.MVL 139, mazbata from the Tuzla district council (29 Rebí'ü'l-evvel 1256 [31 May 1840]): 'bizler bunlar içün iyüdir demiş olsak ahāliniñ re'ylerine mütāba'at itmeyüb'.

${ }^{120}$ See most typically Shaw 1968. 
Citation : Aymes, Marc (2007) 'The Voice-Over of Administration: Reading Ottoman Archives at the Risk of III-literacy',

European Journal of Turkish Studies, Thematic Issue $\mathrm{N}^{\circ} 6$, III-literate Knowledge, URL: http://www.ejts.org/document1333.html

To quote a passage, use paragraph (§).

needs to be tempered - as clearly appears while reading another round robin, contemporary of the Tuzla document and dealing with the same topic, issued by the Lefkoşa council (and probably by the Cyprus governor himself, for that matter):

[97] When the archbishop was questioned about the arrangements and agreements regarding the kocabaşıs, the aforesaid bishop declared that those who currently are members of the council, namely the head kocabaşı Yānko, Hācī Kerkerī and Äbeydo, were fit. And when asked about the latter's condition and situation, the other council members answered 'Nobody is fitter than these ones.' And when told that according to a sublime order's stipulations an inquiry into the situation of these members had to be undertaken among the humble ones, their answer was as follows: 'Except for these members nobody in the island of Cyprus is fit, and besides one should take heed of not letting words fall to the feet because of their admission.' Consequently, since in truth nobody else seems apt, the necessary steps have been taken ${ }^{121}$.

[98] I adopted a literal translation here: 'letting words fall to the feet' (söz ayaġa düşmek). Yet this phrase, in its figurative sense, points to authority matters: it refers to the fear that the rabble (ayak takımı) would gain the upper hand in affairs of importance (Redhouse 1890: 284). The fear of order being turned upside down, as it were. Most noticeable here is the fact that an order from the sultan had precisely commanded local authorities to inquire into what 'the humble ones' think - an enfranchisement of public speech whose unusual character prompts an immediate contestation among the duly entitled 'word keepers.' And it is not surprising that their plea gets backup from the local governor, in complete disregard for the order received from Istanbul, since this attitude most surely dovetails with the self-assured pattern detected earlier in the administrators' archives: the multitude does not talk, it has no word; so why should it be listened to? Little here has to do with any tentative principle of representativeness; rather, the reaction of the Cyprus authorities remains in line with an age-old paternalism.

${ }^{121}$ BOA, I.MVL 139, mazbata from the Lefkoşa council, more specifically written in the name of the governor 'Osmān Nūrī (n.d. [ 1840]) (emphasis added): 'kocabaşıları̃̃ tertīb ü tensībi dahī baş piskoposa lede-s-su'āl el-yevm a'zā-yı meclis olan baş kocabaşı Yānko ile Hācī Kerkerī ve Ābeydo münāsib oldıg̉ını piskopos-ı mersūm tarafından haber virilüb keyfiyet ü hālleri kusūr-ı a'zā-yı meclisden dahī tahkīk kılındıkda bunlardan münāsibi yokdur deyü cevāb virilmiş ve bu a'zā-yı meclisiñ keyfiyeti fukarādan dahī tahkīk olunmak irāde-i seniyye iktizāsından oldıg̉ı ifāde olundukda şu a'zādan ġayri Kıbrıs cezīresinde münāsib kimesneler olmayub yine bunlar olacaklarından söz ayaġa düşmemek münāsibdir yollü cevāblarına ve hakīkat bunlardan başka ehilleri dahī görülmedigine nazaren īcābı icrā olun[ması] [...].' 
Citation : Aymes, Marc (2007) 'The Voice-Over of Administration: Reading Ottoman Archives at the Risk of III-literacy',

European Journal of Turkish Studies, Thematic Issue $N^{\circ} 6$, III-literate Knowledge, URL: http://www.ejts.org/document1333.html

To quote a passage, use paragraph (§).

[99] The attempt at fencing off one's monopoly on literate words thus inextricably ties in with the maintenance of an oligarchic form of authority. Both draw on a conceptual dichotomy which radiates paramount in the Ottoman linguistic universe: on the one hand, commoners ('avāmm) ${ }^{122}$; on the other, the distinguished ones (havāss) ${ }^{123}$. Not only does this divide denote homespun sociopolitical ${ }^{124}$ as well as mystical ${ }^{125}$ hierarchies; it also harbours a variety of implications as to language, written and spoken: 'the differences between the language of the literate class (the havass) and the people (the avamm) [...] were considerable, ${ }^{126}$. The former master a culture of letters, and nurture it with eloquence and distinction ${ }^{127}$; the latter only can use vulgar and flawed turns of phrase ${ }^{128}$. In short, they do not speak the same language.

${ }^{122}$ Redhouse 1890: 1279 ('āmme (pl. a'vāmm): 1. Common, universal. 2. The commonalty; the vulgar masses, the public. 3. The whole body of a class. 4. The lay members of a people').

${ }^{123}$ Ibid.: 869 ('havāss: 1. That are special, peculiar, or particular. 2. People of distinction; notables; men of learning, men of piety. 3. Intimate friends; confidential attendants. 4. Special qualities, properties, essences. 5. Private domains of the sovereign. 6 . Places assigned to the jurisdiction of a particular government. 7. Rare or precious articles').

124 Ibid.: 869 ('hāssa ve 'avāmm: The specialty and the commonalty of mankind'), as well as 1279 ('1. State servants and the public. 2. Professional men and the lay community'). Beg (1978) provides insights into this dichotomy's antecedents in Arabic. On the Ottoman Turkish side see Strauss 1996: 232. Also Levend 1973: 31 ('havas denilince okumuşların seçkini, avam denilince de, [...] anadan doğma bilgisiz, anlayışsız, kaba kişiler anlaşılmış, hatta avam, ayaktakımı karşılığı olarak bile kullanılmıştır'). And Makdisi 2000: 47 ('The chronicles, which were expressions of the social order, consistently used the terms 'umum, 'amma, a'wam (Ott. halk) to distinguish the 'commoner' ahali from the notable awjuh and a'yan (Ott. söz sahibleri)'; p. 77: 'secular division between the söz sahibleri and the ahali.').

${ }^{125}$ See Uludağ 1991: 105 ('Avam: Inanç ve ibadetleri genellikle taklide dayanan, dinin şekil ve merasimlerinin ötesine geçemeyenler için kullanılan bir tasavvuf terimi') and $1997: 517$ ('Tasavvufta genellikle ibadet, hal, ahlâk, edep, ilim ve irfan üçlü bir sınıflandırmaya tâbi tutulur. Buna göre meselâ bir ahlâk kuralı alelâde, iyi veya en iyi şekilde uygulanabilir. Avam bu kuralları alelâde, havas iyi, hâssü'l-havâs ise en iyi şekilde yerine getirir.')

${ }^{126}$ Strauss 1996: 232. One may also quote Mardin $2002: 120$ ('It is reported that when the historian Ibn Kemal [...] began writing the history of the Ottoman dynasty (Tevârih-i âl-ı Osman), the ruling Sultan, Bayazid II (1481-1512) entreated him to write in a way comprehensible to higher and lower classes (havas ve avam), asking him to be clear (vazih) and 'without caring for the affectations of rhetoricians'.' After Alessio Bombaci, 'The Turkish Literature', in Pertev Naili Boratav (ed.), Philologiae Turcica Fundamenta vol II, Wiesbaden, Franz Steiner, 1965, p. 67-68). Kemal Silay's study (1994) adds further layers to these complex language matters.

${ }^{127}$ See Ahmed Cevdet Paşa, Belāgat-ı 'osmāniyye, Istanbul, 1'st ed. 1881, p. 12 (as translated by Strauss 1997: 279): 'L'éloquence, ce sont des mots dont la prononciation et l'audition est douce et la signification évidente, c'est-à-dire que la signification de ces mots, dès qu'ils sont prononcés, entre dans l'esprit. Cela se traduit aussi par ce que les mots correspondent aux règles de la grammaire et sont beaucoup employés par 
Citation : Aymes, Marc (2007) 'The Voice-Over of Administration: Reading Ottoman Archives at the Risk of III-literacy',

European Journal of Turkish Studies, Thematic Issue $N^{\circ} 6$, III-literate Knowledge, URL: http://www.ejts.org/document1333.html

To quote a passage, use paragraph (§).

[100] Is this what may be called diglossia? The question has been debated, and still remains undecided $^{129}$. Drawing on what precedes, though, one may hold one conclusion sure: if diglossia there is, it manifests itself not only in a strictly linguistic field ${ }^{130}$, but also on the margins of it, where language abilities merge with questions of authority and legitimacy. One last document helps perceive this coalescence. It is a report sent to Istanbul by the governor-general of the Mediterranean islands in May 1868, regarding his visit to Cyprus and the matter of locusts:

[101] Since for twenty-two years this question has made great demands in goods and pains from the inhabitants, and none of this care and dedication have fully yielded fruit, the idea that there is no way to get rid of it has pervaded the opinion of commoners [efkār-ı 'āmme], and the people [āhād-ı nās] are dispirited; moreover, because some notables [mütehayyizān] of this country have ended up considering the annual salary that they receive for being in charge of the locusts as their livelihood, they must not work at destroying them if they want not to be deprived of this sum ${ }^{131}$.

les lettrés. Car les spécialistes de la langue, les lettrés, font passer la langue par un tamis subtil et recherchent et choisissent de tels mots. Ils évitent l'emploi de mots lourds à la langue et qui déplaisent à l'oreille, et qui demandent de recourir à un dictionnaire et de se fatiguer la pensée et l'esprit pour en comprendre le sens. On dit que le meilleur discours est celui dont le peuple (avamm) comprend le sens, et dont les gens instruits (havass) apprécient aussi les talents et les avantages.'

${ }^{128}$ See Pellat 1986: 609 ("fautes de langage commises par le commun', [c']est une expression qui caractérise une branche de la lexicographie destinée à corriger les déviations par rapport à la norme linguistique que des puristes constatent chez leurs contemporains').

${ }^{129}$ Strauss's cautious answer to this question is affirmative (1996: 233). Mardin (2002: 116) argues for the reverse, with a slightly paradoxical line: 'despite the imputed use of two antithetical languages in the Ottoman empire - one 'polite', cosmopolitan, and made up of Turkic, Arabic and Persian roots, the other folkic vernacular - a common substratum of 'Turkishness' was maintained across the varieties of linguistic code. This was achieved through the hegemonic position of the cosmopolitan hybrid language of state, which remained 'Turkish' by affirming its difference from the other languages spoken in the empire'.

${ }^{130}$ Indeed the notion of 'diglossia' calls first and foremost for a 'sociolinguistical' definition. See Strauss 1996: 230 (after Charles Ferguson, 'Diglossia', Word n 15/2, 1959, p. 325-340): 'il s'agit d'une situation linguistique qui réunit deux variétés d'une seule et même langue, où, outre la ou les variétés acquises en premier lieu variétés qui peuvent compter un standard ou des standards régionaux ('dialectes') - on trouve aussi une variété superposée, qui se caractérise par les traits suivants: a) elle est très divergente et hautement codifiée, souvent plus complexe au niveau grammatical que les variétés acquises en premier lieu; b) elle est le support d'une vaste et prestigieuse littérature écrite; c) elle est utilisée à l'écrit ou dans les situations formelles du discours; d) elle n'est pas utilisée dans la conversation courante.'

${ }^{131}$ BOA, I.ŞD 301, report by the governor-general (vāll) of the White Sea Islands Es-seyyid Ahmed Paşa (16 Muharrem 1285 [9 May 1868]): 'şimdiye kadar yigirmi iki seneden-berü bu işde ahāliniñ mālen ve bedenen itdikleri i'āne ve hidmet semere-i kāmileyi müntic olmadıġından bunuñ husūl-i indifā'ı mümkün olamayacaǵı efkār-ı 'āmmeye birleşmiş oldıg̉ından nāşī āhād-ı nās meftūr ve ba'zı mütehayyizān-ı memleket dahī beher 
Citation : Aymes, Marc (2007) 'The Voice-Over of Administration: Reading Ottoman Archives at the Risk of III-literacy',

European Journal of Turkish Studies, Thematic Issue $N^{\circ} 6$, III-literate Knowledge, URL: http://www.ejts.org/document1333.html

To quote a passage, use paragraph (§).

[102] Again, the argument here breaks down into two separate categories: 'commoners' (or 'the people' ${ }^{132}$ ) and 'notables' ${ }^{133}$. The matter in hand has nothing to do with language; still the administrator's framing presupposes an all-pervading sociolinguistic divide.

[103] 'Every place in this island is fertile and fruitful, to the extent that it is impossible to describe it with a pen ${ }^{134}$. However paper-producing and paper-pushing the bureaucratic world of Ottoman officials was, there always came a moment when their pen was brought to a standstill. Then they realized or remembered that their writing could not by itself sustain any stable and ever-readable meaning. Riddled with innumerable blanks, distorted by incoercible bulges, their letters remained versatile and fragile. Most of what their literacy meant, in short, rested somewhere else than in the realm of the written word, in the twilight zone where letters melted away into provincial ill-literacy.

[104] What bearing does such a conclusion have on today's scholarly treatment of these documents-turned-archives - that is, on the historians' own reading (hence writing) abilities ${ }^{135}$ ? Inevitably, one ends up wondering: if these archives are to be considered oral, how to ascertain that the

sene me'kel hükmüne girmiş olan çekirge me'mūriyeti ücretinden mahrūm olmamak üzere bunuñ kāmilen itlāfı emrinde bi-hakkin çalışmamag̉a mecbūr.'

132 Redhouse 1890: 2062 ('nās: 1. Men, mankind. 2. The common people, the mob, the public'; and p. 34: 'āhād-ı nās: Individual people, individuals, the commonalty of mankind'). The word also releases linguistic connotations (ibid.: 'lisānü-n-nās: 1. The evil-speaking practiced by men. 2. The vulgar tongue').

${ }^{133}$ Ibid.: 1689 ('mütehayyiz: 1. Existent, occupying a place. 2. Included in a class. 3. Distinguished, who occupies attention'). This word, as much as 'hātılü' and 'havāss', can be considered a close Ottoman Turkish equivalent to the title of 'notable.'

${ }^{134}$ BOA, I.ŞD 301, report from the governor-general of the White Sea Islands Es-seyyid Ahmed Paşa (16 Muharrem 1285 [9 May 1868]): 'bu atanıñ ise her tarafı kalem ile tavsīfi mümkün olamayacak sūretde münbit ve mahsūldār oldıği'.

${ }^{135}$ Concerning the crucial distinction between documents and archives, see Anheim, Poncet 2004: 3 ('Les sources archivées dont dispose l'historien ont été fabriquées en deux temps: une première fois en tant que documents, une seconde en tant qu'archives, c'est-à-dire des documents conservés, classés et inventoriés.'); and Dardy 2001: 89. Along this line, one may also stress the 'institutive' character of 'the archive' (Derrida 1995; Vizenor 1998). All in all, one can but conclude that much remains to be researched concerning the twists and turns of the archivation process that took place in the Ottoman Empire during the $19^{\text {th }}$ and early $20^{\text {th }}$ centuries. 
Citation : Aymes, Marc (2007) 'The Voice-Over of Administration: Reading Ottoman Archives at the Risk of III-literacy',

European Journal of Turkish Studies, Thematic Issue $\mathrm{N}^{\circ} 6$, III-literate Knowledge, URL: http://www.ejts.org/document1333.html

To quote a passage, use paragraph (§).

voice-over which secured their plain authority can be retrieved? If, on balance, what weighed most was the looming vertigo of unpenned overtones and rumours, could it be that the innumerable documents kept in the Ottoman archives to date reveal but mute or garbled writings?

[105] In an attempt to overcome this apparent dilemma, one should revise and amend the conclusion provided above, whose formulation remains flawed. For, as already made clear earlier in the present issue (see its introduction), ill-literacy is not simply a matter of oral utterances versus written words: it also points to a tangle of heterogeneous, mutually contaminating graphic norms, which the 'literate' strive to unravel according to their own sense of authority. Rogue voices, in other terms, did make inroads into the correspondence of administrators. However forceful the latter's attempts to silence them, and to reduce them to a policed taxonomy, they have left their imprint on the archives we read today (or else, how could we read them?). Luckily enough, while imperilling the period administrators' routines, this ill-literacy is also poised to flabbergast the historian's temperate readings. 
Citation : Aymes, Marc (2007) 'The Voice-Over of Administration: Reading Ottoman Archives at the Risk of III-literacy',

European Journal of Turkish Studies, Thematic Issue $\mathrm{N}^{\circ} 6$, III-literate Knowledge, URL: http://www.ejts.org/document1333.html

To quote a passage, use paragraph (§).

\section{Abbreviations}

- BOA: Başbakanlık Osmanlı Arşivi, Istanbul

— A.DVN: Bâb-ı Âlî belgeleri - Sadâret Dîvân Kalemi belgeleri

— A.DVN.MHM: Bâb-ı Âlî belgeleri - Sadâret Dîvân Kalemi belgeleri - Mühimme Kalemi

- A.DVNS.MHM.d: Divân-ı Hümâyûn ve Bâb-ı Âsafî defterleri - Mühimme defterleri

-A.MKT: Bâb-ı Âlî belgeleri - Mektubî Kalemi

—I.DH: Irâde - Dâhiliye

- I.HR: Irâde - Hâriciye

- I.MVL: Irâde - Meclis-i Vâlâ

— I.ŞD: Irâde - Şûrâ-yı Devlet

- MAE: Archives du ministère des Affaires étrangères, Paris

- CCC: Correspondance consulaire et commerciale

$-\mathrm{CPC}$ : Correspondance politique des consuls

- PRO: Public Record Office [National Archives of the United Kingdom], Kew

— FO: Foreign Office

- El2: Encyclopaedia of Islam, $2^{\text {nd }}$ ed. (page numbers refer to the French edition) 
Citation : Aymes, Marc (2007) 'The Voice-Over of Administration: Reading Ottoman Archives at the Risk of III-literacy',

European Journal of Turkish Studies, Thematic Issue $N^{\circ} 6$, III-literate Knowledge, URL: http://www.ejts.org/document1333.html

To quote a passage, use paragraph (§).

\section{References}

Akyıldız, Ali (1995) 'Tanzimat Döneminde Belgelerin Şekil, Dil ve Muhteva Yönünden Geçirdiği Bazı Değişiklikler (1839-1856)', Osmanlı Araştırmaları xv, pp. 221-237.

Anagnostopoulou, Athanasia (2002) 'Les Rapports de l'Église orthodoxe avec le Kapudan Pacha (fin du XvIII--début XIXe siècle)', in Zachariadou, Elizabeth (ed.), The Kapudan Pasha: His Office and his Domain, Rethymno, Crete University Press.

Anheim, Étienne ; Poncet, Olivier (2004) 'Fabrique des archives, fabrique de l'histoire', Revue de synthèse 125: Fabrique des archives, fabrique de l'histoire, pp. 1-14.

Aymes, Marc (forthcoming) 'Un Grand Progrès - sur le papier': Histoire provinciale des réformes ottomanes à Chypre au xIX $\mathrm{X}^{\ominus}$ siècle, Paris \& Leuven, Peeters.

Başbakanlık Osmanlı Arşivi Rehberi (2000) Ankara: T.C. Başbakanlık Devlet Arşivleri Genel Müdürlüğü, Osmanlı Arşivi Daire Başkanlı̆̆ı.

Beg, M. A. J. (1978) 'Al-Khāssa wa-l-āmma', El², vol. v, pp. 1128-1130.

Bouquet, Olivier (2007) Les Pachas du sultan. Essai sur les agents supérieurs de l'État ottoman (1839-1909), Paris/Leuven, Peeters.

Bulliet, Richard W. (1994) Islam, the View from the Edge, New York: Columbia University Press.

Corbin, Alain (1992) 'Le Vertige des foisonnements. Esquisse panoramique d'une histoire sans nom', Revue d'histoire moderne et contemporaine, 39 (1), pp. 103-126.

Dardy, Claudine (2001) 'L'écriture administrative et ses produits : des carnets aux cartes', in Poueyto, Jean-Luc (ed.), Illettrismes et cultures, Paris, L'Harmattan, pp. 71-90.

Dionyssiou, George (1995) The Implementation of the Tanzimat Reforms in Cyprus (1839-1878): An Assessment of the Greek and Ottoman Evidence from Local Sources, Univ. of Birmingham, Centre for Byzantine, Ottoman and Modern Greek Studies, unpublished Master of Letters thesis.

Eickelman, Dale F. (1978) 'The Art of Memory: Islamic Education and its Social Reproduction', Comparative Studies in Society and History, 20 (4), pp. 485-516.

Fortna, Benjamin C. (2001) 'Learning to Read in the Late Ottoman Empire and Early Turkish Republic', Comparative Studies of South Asia, Africa and the Middle East, XXI (1-2), pp. 33-41.

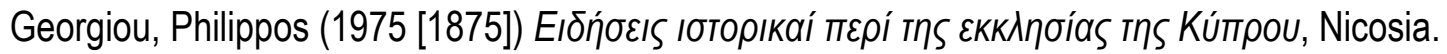

Hill, sir George R. (1972) A History of Cyprus vol. 4: The Ottoman Province - The British Colony, 1571-1948 (edited by sir Harry Luke), London, Cambridge University Press.

Hourani, Albert (1968) 'Ottoman Reforms and the Politics of Notables', in Polk, William R., Chambers, Richard L. (eds.), Beginnings of Modernization in the Middle East: The Nineteenth Century, Chicago/London, University of Chicago Press, pp. 41-68.

İlgürel, Mücteba (2001) 'İstimâlet', Türkiye Diyanet Vakfı İlâm Ansiklopedisi, 23, pp. 362-363. 
Citation : Aymes, Marc (2007) 'The Voice-Over of Administration: Reading Ottoman Archives at the Risk of III-literacy',

European Journal of Turkish Studies, Thematic Issue $N^{\circ} 6$, III-literate Knowledge, URL: http://www.ejts.org/document1333.html

To quote a passage, use paragraph (§).

Kütükoğlu, Mübahat S. (1994) Osmanlı Belgelerinin Dili (Diplomatik), Istanbul: Kubbealtı Akademisi Kültür ve San'at Vakfı.

Lahire, Bernard (1999) L'Invention de l'illlettrisme". Rhétoriques publiques, éthique et stigmates, Paris: La Découverte.

Levend, Agâh Sırrı (1973) Türk Edebiyatı Tarihi, Ankara, Türk Tarih Kurumu Basımevi.

Lowry, Heath W. (2003) The Nature of the Early Ottoman State, Albany, State University of New York.

Makdisi, Ussama (2000) The Culture of Sectarianism: Community, History and Violence in Ottoman Lebanon, Berkeley, University of California Press.

Ma'0z, Moshe (1968) Ottoman Reform in Syria and Palestine, 1840-1861: The Impact of the Tanzimat on Politics and Society, Oxford, Clarendon Press.

Mardin, Şerif (1962) The Genesis of Young Ottoman Thought. A Study in the Modernization of Turkish Political Ideas, Princeton, Princeton University Press.

Mardin, Şerif (1989) Religion and Social Change in Modern Turkey. The Case of Bediüzzaman Said Nursi, Albany.

Mardin, Şerif (2002) 'Playing Games With Names', in Kandiyoti, Deniz, Saktanber, Ayşe (eds.), Fragments of Culture: The Everyday of Modern Turkey, London/New York, I.B. Tauris, pp. 115-127.

Messick, Brinkley M. (1993) The Calligraphic State: Textual Domination and History in a Muslim Society, Berkeley/Los Angeles/Oxford, University of California Press.

Paret, Rudi (1986) 'Kirā'a', El2', vol. v, pp. 129-132.

Parmaksızoğlu, İsmet (1977) 'Rusya'nın Mikenos Adasında Konsolosluk Kurma Teşebbüsü ve Bununla İlgili Vesikalar', Belleten, xl/161, pp. 125-135.

Pellat, Ch. (1986) 'Lahn al-'āmma', El², vol. v, pp. 609-614.

Rancière, Jacques (2004 [1998]) Aux Bords du politique, Paris, Gallimard.

Redhouse, sir James W. (1890) A Turkish and English Lexicon, Istanbul, Boyajian, 1890 (reprint Istanbul, Çağrı yayınları, [1978] 2001).

Reinkowski, Maurus (2003) 'Double Struggle, No Income: Ottoman Borderlands in Northern Albania', in Karpat, Kemal H. (ed.) (with Robert W. Zens), Ottoman Borderlands: Issues, Personalities and Political Changes, Madison, The University of Wisconsin Press.

Reinkowski, Maurus (2005) Die Dinge der Ordnung: Eine vergleichende Untersuchung über die osmanischen Tanzimat, Münich, Oldenbourg.

Savile, A. R. (1878) Cyprus, London.

Shaw, Stanford J. (1968) 'The Origins of Representative Government in the Ottoman Empire: An Introduction to the Provincial Councils, 1839-1876', in Winder, R. Bayly (ed.), Near Eastern Round Table 1967-68, New York, Near Eastern Center and Center for International Studies.

Silay, Kemal (1994) Nedim and the Poetics of the Ottoman Court: Medieval Inheritance and the Need 
Citation : Aymes, Marc (2007) 'The Voice-Over of Administration: Reading Ottoman Archives at the Risk of III-literacy',

European Journal of Turkish Studies, Thematic Issue $\mathrm{N}^{\circ} 6$, III-literate Knowledge, URL: http://www.ejts.org/document1333.html

To quote a passage, use paragraph (§).

for Change, Bloomington, Indiana University.

Strauss, Johann (1996) 'Diglossie dans le domaine ottoman. Évolution et péripéties d'une situation linguistique', Revue des mondes musulmans et de la Méditerranée, 75-76, pp. 221-256.

Strauss, Johann (1997) 'La Conversation', in Dumont, Paul, Georgeon, François (eds.), Vivre dans l'Empire ottoman. Sociabilités et relations intercommunautaires (xviiie-xxe siècles), Paris, L'Harmattan, pp. 261-318.

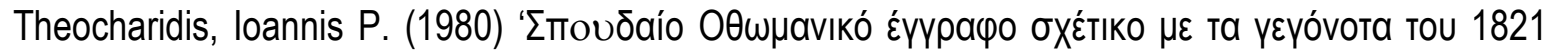

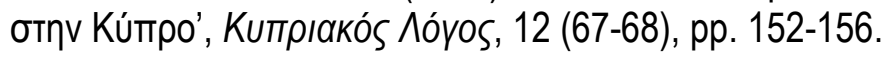

Uludağ, Süleyman (1991) 'Avam', in Türkiye Diyanet Vakfı Islâm Ansiklopedisi, vol. 4, pp. 105-110.

Uludağ, Süleyman (1997) 'Havas', in Türkiye Diyanet Vakfı İslâm Ansiklopedisi, vol. 16, p. 517.

Uzun, Ahmet (2002) Tanzimat ve Sosyal Direnişler. Niş İsyanı üzerine Ayrıntılı bir Inceleme (1841), Istanbul, Eren. 